\title{
Marginal Pricing and Student Investment in Higher Education*
}

\author{
Steven W. Hemelt \\ University of North Carolina \\ at Chapel Hill
}

\author{
Kevin M. Stange \\ University of Michigan \\ and NBER
}

October 2015

\begin{abstract}
$\underline{\text { Abstract }}$
This paper examines the effect of marginal price on students' educational investments using rich administrative data on students at Michigan public universities. Marginal price refers to the amount colleges charge for each additional credit taken in a semester. Institutions differ in how they price credits above the full-time minimum (of 12 credits), with many institutions reducing the marginal price of such credits to zero. We find that a zero marginal price induces a modest share of students (i.e., 7 percent) to attempt up to one additional class (i.e., 3 credits) but also increases withdrawals and lowers course performance. The analysis generally suggests minimal impacts on credits earned and the likelihood of meeting "on-time" benchmarks toward college completion, though estimates for these outcomes are less precise and more variable across specifications. Consistent with theory, the effect on attempted credits is largest among students who would otherwise locate at the full-time minimum, which include lower-achieving and socioeconomically disadvantaged students.
\end{abstract}

\footnotetext{
* The research reported here was supported by the Institute of Education Sciences (IES), U.S. Department of Education, through Grant R305B110001 to the University of Michigan. The opinions expressed are those of the authors and do not represent views of the Institute of Education Sciences or the U.S. Department of Education. This research used data structured and maintained by the Michigan Consortium for Educational Research (MCER). MCER data are modified for analysis purposes using rules governed by MCER and are not identical to those data collected and maintained by the Michigan Department of Education (MDE) and/or Michigan's Center for Educational Performance and Information (CEPI). Results, information. and opinions solely represent the analysis, information and opinions of the author(s) and are not endorsed by, nor do they reflect the views or positions of grantors, MDE and CEPI or any employee thereof. Monica Hernandez, Andrew Litten, and Chris Zbrozek provided excellent research assistance. We are grateful for helpful comments from John DiNardo, Susan Dynarski, Caroline Hoxby, Sarah Turner, Leslie Turner, and seminar participants at the University of Michigan, Stanford University, CUNY, the W.E. Upjohn Institute, and the NBER Education Program Fall 2013 meetings. Hemelt can be contacted at hemelt@email.unc.edu; Stange can be contacted at kstange@umich.edu. All errors and opinions are our own.
} 


\section{Introduction}

Only slightly more than half of recent college entrants graduate within six years (Shapiro et al., 2013) and time-to-degree has increased particularly for students from low-income families (Bound, Lovenheim, \& Turner, 2012). Such statistics have propelled those in federal, state, and local policy circles to call for proposals aimed at increasing rates of degree completion and shortening time-to-degree among college-goers (e.g., National Conference of State Legislatures, 2010). Indeed, recent proposals from the Obama administration suggest tying federal aid to graduation rates and timely degree completion (Lewin, 2013).

In the face of such pressure, many institutions have looked at changes in tuition policies as a means of generating revenue while also maintaining or improving student success. Marginal price is an important dimension of institutions’ pricing structures about which little is known. By marginal price, we mean the price students are charged incrementally for each additional course (or credit) they take in a given semester. Many students only take the minimum course load to achieve full-time status (i.e., 12 credits), which at most institutions would translate to earning a Bachelor's degree in five years or more. At some institutions, the marginal price of credits taken above 12 is zero; others have a linear, per-credit marginal price for all credit levels. Indeed, some institutions have adopted “flat” pricing (i.e., zero marginal cost for credits above 12) in explicit expectation that students will respond by attempting and earning more credits and graduating faster. ${ }^{1}$

How individuals react to nonlinear price schedules is central to many areas of economics and policymaking, as proposals in a variety of domains are predicated on the microeconomic

\footnotetext{
${ }^{1}$ From an institution's perspective, while there may be some concern about losing revenue when switching from a per-credit to a flat-pricing approach, savings may also result from students graduating in a timelier manner. In addition, institutions particularly concerned about such revenue losses may choose to slowly increase the price charged for 12 credits over time to counteract any losses from a flat-pricing approach (Baum, McDemmond, Jones, 2014).
} 
principle that individuals respond to marginal price. The design of the Earned Income Tax Credit (EITC), many savings and retirement programs, and public health insurance programs all incorporate nonlinear price schedules to achieve policy goals, as do pricing schedules in many consumer markets such as phone and energy services.

Whether and how individuals respond to these marginal incentives remains largely an open question with recent empirical evidence from other contexts mixed and no evidence from the setting of education. ${ }^{2} \mathrm{~A}$ weak evidence base has not prevented colleges from touting nonlinear pricing as one solution to colleges' goals of increasing timely graduation rates. For example, Adams State in Colorado recently made such a switch from per-credit (linear) to flat (nonlinear) pricing, citing this shift as the reason average credit hours have increased in just two years (Mumper, 2012). Similar policy shifts have been observed at Montana State, the University of Texas, and many other institutions (Baum, Conklin, \& Johnson, 2013). However, whether nonlinear pricing alters students' investment intensity as predicted by economic theory is not known.

This paper is the first to examine the effect of marginal price on educational investment. We focus on the effect of exposure to a "flat" pricing scheme at a university, wherein the marginal price of additional credits above the full-time minimum is zero, relative to a linear tuition-pricing scheme. Our contributions are fourfold. First, we add to the growing evidence base on whether individuals respond to marginal incentives embedded in nonlinear price schedules, albeit in a new and policy-important context. As human capital investment is one of

\footnotetext{
${ }^{2}$ Saez (2010) finds that the self-employed respond to the first kink in the nonlinear EITC schedule, but the response to subsequent kinks and for wage and salary workers is minimal. Ito $(2013,2014)$ finds that electricity and water consumers respond to average price, not the marginal price embedded in the nonlinear price schedules they face. For evidence from other settings, see Hausman (1981) for federal income tax, Friedberg (2000) for retirement savings plans, Kowalski (2012) for health insurance, Olmstead, Hanemann, and Stavins (2007) for water, and Borenstein (2012) for energy services. In their review of the transfer and human capital programs created in the 1960s, Bitler and Karoly (2015) conclude that individuals respond to the marginal incentives embedded in many of these programs. Moffitt (1990) reviews the early literature on nonlinear pricing.
} 
the most important economic decisions individuals make, evidence about whether the standard model applies to this setting is useful. Second, we exploit variation in the pricing structure faced by similar individuals in very similar choice contexts. Much of the previous literature on nonlinear budget constraints focuses on contexts in which similar individuals face the same price structure (e.g., the federal tax code), which creates numerous econometric problems such as the fact that tax rates (and thus marginal incentives) are endogenous or that individuals with different marginal incentives may be quite different. ${ }^{3}$ Third, we provide the first evidence on the effects of a policy that many higher education institutions and states have turned to as a way to boost timely degree completion. Identifying effective policies has become critical as federal and state funding is increasingly tied to graduation rates and timely degree completion (National Conference of State Legislatures, 2010; Lewin, 2013). ${ }^{4}$ Finally, our study informs the revenue consequences of institutions’ pricing regimes. Public institutions increasingly rely on tuition revenue to supplant declines in state appropriations and many have avoided across-the-board tuition increases, instead altering other features of their pricing policies.

We assess the effect of marginal price using administrative data on all Michigan public high school graduates in the classes of 2008 through 2011 who attended one of the state's public universities. Michigan is a compelling setting to study, as there is substantial policy variation across very similar institutions, which is not present in other states. ${ }^{5}$ Figure 1 depicts the price schedule at two pairs of Michigan’s fifteen public universities. Each pair of universities has an

\footnotetext{
${ }^{3}$ Ito $(2013,2014)$ are exceptions. Moffitt (1990) reviews several of the econometric problems and Saez, Slemrod, and Giertz (2012) discuss similar issues in the context of taxable income.

${ }^{4}$ Lengthening time to degree is not solely an issue for postsecondary institutions. It is costly for students as well. Students that set themselves on a longer path to college completion forego time in the labor market, demand more resources to finish, and may heighten risks of stop-out.

${ }^{5}$ Our study focuses on public universities in Michigan because of the availability of rich transcript data and because the state appears unique in having substantial policy variation among similar institutions, likely because tuition policy is not set centrally. While focusing on a single state and sector controls for many possible confounders, it raises the question of external validity. We discuss the issue of external validity in Appendix D and present evidence from two other states that supports our conclusions from the Michigan experience.
} 
identical interquartile range of student ACT scores and similar prices for part-time students, yet quite different marginal prices for full-time students. Full-time students at Western Michigan and University of Michigan-Flint pay little additional tuition for courses taken beyond the full-time minimum, in contrast to those at Central Michigan and Ferris State. Of all public universities in the state, eight charge full-time students per credit taken, while students at the other seven pay greatly reduced marginal tuition. ${ }^{6}$ The subsidy embedded in this nonlinear price structure is substantial: 20 percent of the direct costs of college among those who take five classes in a semester ( $\$ 740$ to $\$ 1,260$ for each additional 3-credit course). Though there are some differences in the characteristics of students attending institutions with per-credit pricing and those with flat pricing, there is considerable overlap between these two groups. We rely on a selection-onobservables assumption combined with this institutional overlap to identify the causal effect of marginal price on credit accumulation. Conditional on our rich set of individual controls, we assume that students are not choosing universities based on the marginal pricing policy. We think this is a reasonable assumption in this case given that tuition information advertised in college guidebooks and financial aid packages is for the average or typical student, which by definition does not vary with credit load.

We find that exposure to flat tuition pricing has only a small (statistically insignificant) effect on the average number of credits attempted, but induces a modest share (7 percent) of students to attempt a few more credits (i.e., up to one course, or 3 credits, more). Yet, we find little evidence that these additional attempted credits translate into more earned credits in a semester. Students facing no marginal price are more likely to withdraw from at least one course and also have lower GPAs. Accordingly, flat pricing is not associated with increased cumulative

\footnotetext{
${ }^{6}$ Flat pricing institutions typically charge additional tuition beyond some upper threshold (typically 18 credits) and two charge very modest additional tuition beyond 12 credits.
} 
credits earned, greater persistence, or reduced time-to-degree, though estimates of these outcomes are admittedly imprecise. Theory predicts that the greatest attempted-credit response would be among students who would take the full-time minimum under linear pricing (largely minority and economically disadvantaged students in the bottom of the achievement distribution), which is precisely what we find. There is no evidence to suggest that this pricing structure influences students’ decisions to enroll part- versus full-time, likely because any marginal pricing effect is swamped by discontinuities in financial aid eligibility or other considerations. Various approaches to eliminating observed differences - rich controls, sample restrictions, propensity score re-weighting, exact matching on observables - as well as various alternative specifications all suggest similar qualitative results.

For institutions that currently do not charge students at the margin, our results suggest that increasing the marginal price associated with credit intensity will minimally affect students’ rate of progress towards degree and on-time degree completion and may thus be a nondistortionary way of raising revenue. For institutions that currently charge per-credit, eliminating the marginal price is unlikely to improve student outcomes. However, our analysis does not fully address other possible effects of marginal pricing, including major choice, interest exploration, or financial burden.

This paper proceeds as follows. The next section discusses previous literature, with a focus on the relationship between tuition pricing and progress through college. Section III provides background on university pricing in the Michigan context. Section IV presents a simple theoretical framework to guide our empirical work and help with interpretation of results. Section V describes the data used in the analyses and our empirical strategy. Section VI presents 
results on credit-taking and student performance and explores their robustness. Section VII concludes.

\section{Previous Literature}

There is a large body of evidence showing that students' enrollment, persistence, and college choices are influenced by net college price. A consensus estimate is that a $\$ 1,000$ change in college price (1990 dollars) is associated with a 3 to 5 percentage point difference in enrollment rates (Kane, 2006; Dynarski, 2003). Evidence on the effect of college price on persistence and degree completion is rarer, but most studies suggest that persistence and completion are modestly responsive to prices for at least some groups (Bettinger, 2004; Turner, 2004; Dynarski, 2008; DesJardins \& McCall, 2010; Goldrick-Rab et al., 2011; Castleman \& Long, 2013). Price also appears to be a strong predictor of the specific college students choose to attend (Long, 2004; Jacob, McCall, \& Stange, 2013; Hemelt \& Marcotte, 2015), institution-level enrollment (Hemelt \& Marcotte, 2011), and major choice (Stange, 2015). While suggestive of price response in educational investment, this literature does not speak to whether students respond to changes in marginal, as opposed to average, price.

We are aware of only one study that examines the relationship between marginal pricing and student outcomes. In a working paper, Bound, Lovenheim, and Turner (2010) found that 4year public institutions with per-credit pricing had lower 4-year graduation rates than those with flat pricing. Further, much of the increase in time-to-degree between 1972 and 1992 occurred at institutions that charge on a per-credit basis. ${ }^{7}$ While suggestive, this relationship could be due to student or institutional differences that happen to correlate with marginal pricing, rather than the causal effect of marginal pricing per se.

\footnotetext{
${ }^{7}$ The analysis of per-credit versus flat pricing appeared in two footnotes and was not central to their main analysis so was dropped in the subsequent published version of the paper.
} 
At the same time, a number of interventions have been found to increase students' credit loads, either intentionally or inadvertently. For instance, the Promise Scholarship in West Virginia explicitly tied aid to number of credits (and GPA), and resulted in more students taking 15 credits rather than the full-time minimum (Scott-Clayton, 2010). A similar result was found for a scholarship program at the University of New Mexico (Miller, Binder, Harris, \& Krause, 2011). Yet, work on Georgia’s HOPE scholarship, which tied eligibility and retention of funds to maintaining a 3.0 GPA, found that HOPE reduced the likelihood students took full course loads and increased their propensity to withdraw from classes and divert credits to the summer (Cornwell et al., 2005).

Other conditional aid grant programs (often in conjunction with advising or coaching) have also had impacts on students’ credit loads. For instance, Richburg-Hayes et al. (2009) found that a performance-based scholarship at community colleges in New Orleans increased credit loads, as did an intervention that combined financial incentives and academic support services at a Canadian university (Angrist, Lang, \& Oreopoulos, 2009). At a large Italian university, Garibaldi, Giavazzi, Ichino, and Rettore (2012) found that charging students extra for taking too long to graduate speeds up time-to-degree.

Together, these studies make clear that particular features of scholarship and grant programs can have appreciable effects (positive or negative) on students’ credit loads and progression through college. We look at marginal pricing policy as another potential lever capable of influencing students' credit loads - and ultimately their rates of college completion and average time-to-degree. Since the interventions described above often tie awards explicitly to credit-taking behavior and also typically target select student subgroups, they may not be indicative of the potential effects of marginal pricing. 


\section{Background on University Pricing in Michigan}

During the 2011-2012 academic year, eight of Michigan’s fifteen public 4-year universities charged full-time undergraduate students differently based on number of credits. In these schools, tuition is a linear function of the number of credits taken, ranging from a low of \$246 per credit at Saginaw Valley State University to a high of \$421 at Michigan Technological University. By contrast, the tuition schedule at the other seven institutions has a flat or near-flat range at full-time status (12 credits). Students at these institutions pay a per-credit amount if parttime, but almost no additional monetary cost for taking an additional course once they have reached full-time status. ${ }^{8}$ The upper limit for which the zero marginal price applies varies from 16 to 18 credits. While per-credit pricing is generally more common at less selective institutions (all of the state’s community colleges charge per-credit while the state flagship university, University of Michigan-Ann Arbor, does not), this is not always the case. Further, some institutions have explicitly adopted flat pricing models to encourage students to take 15 credits, while others have switched from the use of flat pricing to charging per credit (e.g., Ferris State in 2008-2009).

Tuition fees apply to any credits attempted in a semester after the course “drop date,” regardless of outcome of the course (pass, fail, withdrawal, etc.). Students are generally given one or two weeks to withdraw from classes while still receiving a full (or near-full) refund of tuition and fees. There does not seem to be any systematic difference in these policies by pricing practice. Flat-pricing institutions in Michigan do not appear to be disproportionately more generous (or strict) in their refund polices than do their per-credit pricing peers.

\footnotetext{
${ }^{8}$ Appendix Table A1 includes more details about the pricing practices of the fifteen institutions. Two institutions, UM-Dearborn and UM-Flint, charge a substantially lower per-credit fee (\$80) once students reach full-time status. We characterize these institutions has having "flat” pricing in our analysis.
} 
Marginal pricing is just one feature of pricing policies at these institutions. During the 2011-2012 academic year, seven charged differentially based on undergraduate level and three charged differently for certain programs or majors (Presidents Council, State Universities of Michigan, 2011). In this regard, Michigan institutions have pricing policies that are quite similar to institutions nationally (Cornell Higher Education Research Institute, 2011; Ehrenberg, 2012).

\section{Theoretical Framework}

\section{A. Basic Model and Predictions}

We develop a static (single-period) model of school intensity choice to better understand how the tuition-pricing schedule alters postsecondary investment. Suppose individual utility depends positively on lifetime consumption $c$ and on time spent not in school, $n$. Thus school attendance incurs effort cost that is increasing with the level of intensity. Individuals choose time spent in school, $z$, to maximize utility $u(c, n)$ subject to a budget constraint and a standard time constraint. ${ }^{9}$ The number of credits taken can be thought of as one measure of $z$. The budget constraint states that consumption equals the sum of endowed income $(I)$ and lifetime earnings minus tuition: $c=I+E(z)-T(z)$. In the single-period model, we simplify things by assuming that each increment of schooling increases earning potential by a fixed amount $w$, thus $E(z)=$ $w z$. This simplification allows us to abstract from effects of nonlinearities in the returns to college education and to focus on the decision about the number of credits taken in a single period. ${ }^{10}$ Tuition is a nonlinear function of credit load, changing discretely as credit load surpasses a threshold $z^{*}$ :

\footnotetext{
${ }^{9}$ The time constraint is that total time spent in $(z)$ and out $(n)$ of school equals total time available, $H: n+z=H$.

${ }^{10}$ Stange (2012) discusses the evidence on and implications of nonlinearities in returns and the dynamic nature of schooling investment. Ignoring the nonlinearities in returns is like ignoring “career concerns” in labor supply models, letting us treat schooling decisions made in different time periods independently. We discuss below how relaxing these assumptions may affect our results.
} 


$$
T(z)=\left\{\begin{array}{c}
t_{0}+t_{1} z \text { if } z<z^{*} \\
t_{0}+t_{1} z^{*}+t_{2}\left(z-z^{*}\right) \text { if } z \geq z^{*},
\end{array}\right.
$$

where typically $t_{1}>t_{2} \cdot{ }^{11}$ Together these elements generate the nonlinear budget constraint depicted by the solid line in Figure 2. Below z* (i.e., the full-time minimum credit load), each increment of schooling investment increases lifetime consumption by $\left(w-t_{1}\right)$. Above $z^{*}$, the net return to each unit of investment is higher and thus the "price" of non-school time is also higher. The dashed line depicts a linear tuition schedule where students pay a constant amount per credit. How individuals respond to nonlinear budget constraints is complex, as reviewed in Moffitt (1990). One finding is that a policy shift from a linear (dashed) to flat (solid) pricing schedule will generate quite heterogeneous responses across students. Students that would locate at $z^{*}$ when facing a linear pricing schedule (denoted by B) experience only a substitution effect (non-school time has become more expensive) and would be predicted to increase their credit intensity. However, students initially choosing to enroll beyond the full-time minimum (denoted by A) also experience an income effect, thus the net effect for this group is ambiguous. Part-time students who would locate below $z^{*}$ when pricing is linear (denoted C) will either remain on the first segment (zero response) or switch segments by increasing credit loads above full-time. ${ }^{12}$ This simple budget set analysis suggests that response may be greatest for students who otherwise would choose to locate at the full-time minimum. In fact, continuous preferences would predict we observe a "hole" in the density of students at the non-convex kink B. Our empirical analysis explores this heterogeneity by stratifying our sample by students’ predicted credits (based on baseline characteristics) when faced with a linear pricing scheme.

\footnotetext{
${ }^{11}$ We also ignore any increased marginal tuition for very high credit loads (typically 17 or 18 credits).

${ }^{12}$ Facing the new pricing schedule, there will be some people that are indifferent between the two segments.
} 


\section{B. Extensions to the Basic Model}

While the basic static model predicts positive (or non-negative) effects of flat pricing on investment intensity for most students (particularly those who would otherwise choose the fulltime minimum), several factors may mitigate this incentive or cause minimal impact on the number of credits that students actually earn. For instance, if the effort cost (essentially how utility decreases with $z$ ) rises sharply around the full-time minimum $\left(z^{*}\right)$, then even large decreases in marginal price could have minimal impact on student course-taking. This may be particularly true since the number of credits is finite and "lumpy" as most classes are worth either 3 or 4 credits. Even if it were optimal to increase credit load by one unit, this may not be feasible for many students. Such adjustment costs have been found to mute responses to nonlinear incentives in other contexts (Chetty et al., 2011).

The basic model also assumes that people choose credit loads with perfect foresight about future effort costs, course completion, enrollment, and degree completion. Generally, current choices will be less responsive to price when uncertainty is high - since the consequences of current decisions depend on these uncertain future outcomes. Related, students may misperceive the true marginal effort cost when making course enrollment decisions by, for instance, being overly confident about their ability to manage a heavier course load. In this case, flat pricing may have different effects on credits attempted and credits earned or could affect course performance. Finally, strong nonlinear returns to degree receipt could mitigate impacts of flat pricing on termlevel course-taking as the nonlinear return would dominate intensity decisions. ${ }^{13}$ While the basic model suggests that reductions in marginal price could induce students to take and earn more credits and speed up degree progress, several realistic extensions demonstrate how this policy lever could be quite muted in practice.

\footnotetext{
${ }^{13}$ In Appendix B, we discuss these factors and develop their implications more formally.
} 


\section{Data and Empirical Approach}

\section{A. Data and Samples}

We combine student-level data from several different administrative sources. From the Michigan Consortium for Education Research (MCER), we begin with information on the universe of Michigan public high school graduates from 2008 through 2011. These data include demographic characteristics during high school (sex, race, ethnicity, free and reduced-price meals eligibility (FARM), limited-English proficiency (LEP), special education status), $11^{\text {th }}$ grade achievement scores, and high school attended. ${ }^{14}$ We then use data from the National Student Clearinghouse (NSC) to restrict our sample to students appearing in college (anywhere up to August 2012). ${ }^{15}$

To examine credit accumulation at Michigan public institutions, we next merge these records of college-going Michigan high school graduates onto data from the Michigan Student Transcript and Academic Record Repository (STARR). STARR contains full, historical transcript records (course-level data) for all individuals enrolled in 2-year or 4-year public colleges in Michigan in the 2011-2012 academic year. While the state of Michigan mandated the collection of entire transcripts of students enrolled at any Michigan public college during that year, there is some (small) variation in the degree to which institutions supplied course-taking information from prior years. Therefore, we focus on STARR data from the Fall of 2011 and Spring of 2012. These semesters occur at different points in an "on-time” college trajectory for students, depending on the year of their high school graduation. For example, the 2011-2012 academic year corresponds to the on-time third year of college for the high school class of 2009.

\footnotetext{
${ }^{14}$ We use a student's composite ACT score since the ACT became a mandatory part of Michigan's high school testing in 2007.

${ }^{15}$ For an extensive overview of the coverage and use of National Student Clearinghouse (NSC) data for research, please consult Dynarski, Hemelt, and Hyman (2015). For the state of Michigan during our timeframe, enrollment coverage is quite high (i.e., between 95 and 97 percent), and highest among 4-year public institutions (100 percent).
} 
Therefore, we also examine whether students' postsecondary persistence (and relatedly, the composition of our sample) is related to flat pricing.

Our main analytic sample includes students from these high school cohorts (i.e., 2008 through 2011) who are enrolled full- or part-time in a Michigan public 4-year institution during the fall and/or spring of the 2011-2012 academic year. This results in 212,473 student-bysemester observations (over 112,000 unique students) across all high school cohorts. For most analyses we restrict our sample to students not attending the University of Michigan-Ann Arbor (187,860 observations) and to only full-time students (171,058 observations excluding UM-AA).

Table 1 presents descriptive statistics on the students and institutions in our analytic sample, as well as college-level credit outcomes by institutional pricing structure. There are some small to moderate differences in the average characteristics of students attending per-credit versus flat-pricing institutions. Overall, students attending flat-pricing schools are more advantaged (less likely to have been eligible for free or reduced-price meals, less likely to be minority) and have higher college admissions scores. Though, as illustrated by the final two columns in Table 1, the achievement advantage of students at flat schools is largely driven by the fact that the University of Michigan-Ann Arbor (UM-AA) uses a flat tuition-pricing schedule. Excluding UM-AA, student characteristics are quite similar at flat and per-credit schools. Flat schools also tend to have more resources and be more selective, but again this pattern reverses when UM-AA is excluded. ${ }^{16}$

Turning to outcome differences, average credit loads of students at flat schools are a bit higher than those at per-credit schools. Indeed, the share of students attempting more than 12 credits in a semester is about 8 to 12 percentage points higher at flat schools than at per-credit

\footnotetext{
${ }^{16}$ In order to achieve greater balance on student characteristics, we drop UM-AA from our main results. However, this has the effect of creating imbalance on institutional resources. Reassuringly, results that include UM-AA are very similar.
} 
institutions. Some mean differences vary more than others as a function of the sample: For example, the share earning 15 or more credits in a semester is about 11 percentage points higher at flat colleges; but, when the University of Michigan-Ann Arbor is excluded from the sample, this difference falls to under 4 percentage points. Obviously, these raw differences in means do not control for other attributes of students and schools that are likely correlated with coursetaking behavior and progress through college.

\section{B. Empirical Approach and Identification Strategy}

Our goal is to compare the behavior of students who face a nonlinear budget constraint (the solid line in Figure 2) to similar students facing a linear constraint (dashed line). Our main approach is to compare credits taken by students attending flat-pricing schools (at which the marginal price is zero for credits above the full-time minimum) to those attending per-creditpricing schools, invoking a selection-on-observables assumption. Since the basic framework predicts heterogeneous responses according to students' course-taking tendencies, we also make such comparisons within narrowly defined student groups. We estimate a linear probability model with Ordinary Least Squares (OLS) of the form:

$$
Y_{i c j t}=\alpha+\beta_{1} \text { Flat }_{j}+\beta_{x} X_{i c j t}+\beta_{z} Z_{j}+\delta_{t}+\theta_{c}+\varepsilon_{i c j t}
$$

In this specification, $Y_{i c j t}$ is a measure of credits attempted or earned by individual $i$ from cohort $c$ attending school $j$ during semester $t$. Our primary outcome variables are total credit load and indicators for attempting or earning a credit load greater than certain thresholds (e.g., at least 13 credits or at least 15 credits). We also examine indicators for course withdrawals and failure, as well as semester GPA. Flat $t_{j}$ is an indicator for whether school $j$ has flat pricing, $X_{i c j t}$ is a vector of student-level measures of achievement and demographics during high school, $\delta_{t}$ is a set of semester fixed effects, $\theta_{c}$ represents cohort fixed effects, and $\varepsilon_{i j c t}$ is a stochastic error 
term. Some specifications control for a limited number of institution-level covariates $\left(Z_{j}\right)$. The primary coefficient of interest is $\beta_{1}$, the effect of flat pricing on our outcome of interest (e.g., student credit-taking or course performance). To account for correlation in the errors among students at the same college, one would usually employ traditional clustering methods at the institution level. However, since cluster-robust standard errors perform poorly in settings with few clusters, we use the wild-bootstrap cluster procedure developed by Cameron, Gelbach, and Miller (2008). A drawback of this procedure is that it is not possible to generate estimates of the standard errors or confidence intervals, thus we report p-values throughout.

The main identifying assumption of our approach is that unobserved student- and institution-level determinants of outcomes are uncorrelated with pricing structure. Conditional on our rich set of individual controls, we assume that students are not choosing universities based on the marginal pricing policy. We think this is a reasonable assumption in this context because the marginal pricing policy is not terribly salient to potential enrollees; college guidebooks stress the average or typical list price and financial aid packages are based on total cost-of-attendance for a typical student, which (by default) does not vary with credit load. The marginal price becomes salient at the point when students register for classes.

We address three remaining possible sources of bias in this basic model. First, students attending "flat" schools may possess different characteristics that are correlated with college performance than those attending per-credit schools. While this is certainly true overall, it is worth noting that there is considerable student overlap on observable characteristics across institutions. Figure 3 depicts the inter-quartile range of ACT scores for all fifteen institutions. With the exception of the University of Michigan-Ann Arbor (a flat pricing school), every flat school has several non-flat schools with considerable test score overlap. Further, we control for a 
rich array of student-level characteristics including ACT score, sex, race, free and reduced-price meal eligibility, limited English proficiency, and special education status. ${ }^{17}$ Our sample size permits us to do this extremely flexibly by looking within student groups defined very narrowly by full interactions between these characteristics. In addition, we estimate models that instrument for pricing structure using the policy of the nearest university to students' high schools or that include high school fixed effects.

Second, additional financial aid could offset the additional tuition and fees associated with additional credits, diminishing the treatment. Grant programs may explicitly increase in value as number of credits increases or cost-of-attendance could be adjusted upwards (increasing eligibility) when additional credits are taken. By design at the federal level, the maximum Pell amount increases discretely at quarter-time, half-time, three-quarters-time, and full-time, but does not increase in value beyond 12 credits. We are not aware of any institution, state, or federal programs that explicitly increase aid for additional credits taken beyond 12. Further, most students who receive the Pell at these universities are receiving the maximum amount, so increases in their cost-of-attendance due to higher credit loads will not increase the amount of grant aid for which they are eligible.

Finally, it is possible that schools’ pricing schemes coincide with other college-level attributes or policies that may influence outcomes, such as resources or advising. Our focus on the public 4-year sector in one state eliminates many institutional differences that correlate with pricing structure nationally, but we cannot entirely rule out this possibility. We take three approaches to address this issue. First, we include an institution-level control for median ACT

\footnotetext{
${ }^{17}$ Figures C1 and C2 in Appendix C plot predicted probabilities of attending a flat-pricing institution (via a probit model) as a function of student-level characteristics (i.e., gender, race and ethnicity, ACT score, FARM, LEP, and special education status) by school type. These graphs illustrate clear common support, regardless of whether we include the University of Michigan-Ann Arbor in our sample.
} 
composite scores of incoming freshman or several other measures of institutional resources.

Second, we examine differences in credit-taking among students attempting less than a full-time load (whose behavior should be minimally affected by the pricing scheme for full-time students) as a falsification test. Third, we exclude University of Michigan-Ann Arbor, which is an outlier both in terms of student characteristics and institutional resources, from our preferred specifications.

It is worth contrasting our simple approach to those employed in other settings with nonlinear pricing. In many settings, similar individuals face the same price structure, so individuals with different marginal incentives are quite different. For instance, much of the variation in marginal incentives in the federal tax code is across families with very different incomes. In addition, the fact that tax rates are determined by income means that marginal incentives are endogenous to many of the outcomes under study (e.g., work behavior). A number of empirical strategies have been developed for these settings, such as measuring "bunching” at budget set kinks (Saez, 2010), instrumenting for tax rates using changes in the tax rate structure (reviewed in Saez, Slemrod, and Giertz (2012)), or structural approaches (Hausman, 1985). Relative to these other methods, our setting permits a very transparent comparison between observably identical students that face quite different marginal incentives.

\section{Results}

\section{A. Distribution of Credits Attempted and Earned}

Figure 4 plots the fraction of all students at or above each credit threshold, separately by pricing policy for our full sample (of students and institutions). We see little difference in the distribution of credits taken (and earned) by part-time students regardless of pricing policy - but, modest differences emerge right at the point where the marginal price diverges between the two 
sets of institutions (i.e., 12 credits). Students that face no marginal tuition price of a heavier course load are more likely to take (and possibly earn) credits beyond the full-time minimum. At first glance, these patterns suggest that marginal pricing policy may have some impact on coursetaking and credit accumulation.

\section{B. Main Results}

The raw differences reported in Figure 4 may overstate the true causal effects of flat pricing because students attending flat pricing schools are slightly higher achieving and advantaged, which likely have independent effects on course-taking. Table 2 presents our main regression estimates, which control for a rich set of individual covariates and median institutionlevel ACT scores and also exclude the University of Michigan-Ann Arbor. ${ }^{18}$ We see no detectable impact of flat pricing on average credits attempted and no evidence that flat pricing affects average credits earned. In this table and throughout much of the paper we focus on fulltime students. Flat pricing does not appear to affect the decision to enroll full-time (i.e., 12 or more credits) and the inclusion of part-time students does not meaningfully change our point estimates for any outcome (columns 3 and 6). ${ }^{19}$ However, including part-time students reduces precision by adding residual variation to our outcomes.

Flat tuition pricing is associated with an increase in the likelihood that students attempt at least 13 credits (more than the full-time minimum) of about 7 percentage points (relative to a base of 79 percent, p-value $=0.03$ ). Since estimates at both the 13 and 15 attempted credit thresholds are similar, this implies that these students are attempting about 3 additional credits,

\footnotetext{
${ }^{18}$ The coefficients on individual covariates are as expected from previous literature: male, non-white, poor, limited English, special education, and students with low ACT all attempt fewer credits. Including many subject tests rather than the ACT composite produces nearly identical results, quantitatively and qualitatively.

${ }^{19}$ The null effect on full-time status also serves as a falsification check: given financial aid and other discontinuities at the full-time threshold, flat pricing should not induce many part-time students to enroll full-time. If we were to find an "effect" of flat pricing at this margin, we might be concerned about other unobserved, college-level attributes correlated with both flat pricing and students' credit-taking behavior driving any other results.
} 
or approximately one course. ${ }^{20}$ Students must earn 15 credits each semester in order to graduate within four years. However, the impact of flat pricing on earned credits is much weaker (i.e., half the magnitude or less of the effect on credits attempted), sometimes "wrong-signed," and insignificant. Therefore, additional attempted credits do not appear to translate into more credits earned.

The inability to translate attempted credits into earned ones is largely explained by course withdrawal. Table 3 examines effects on course withdrawal, failure, and performance (i.e., semester GPA) for all students and just full-time students. In a given semester, flat pricing increases the likelihood that students withdraw from at least one class by about 6 percentage points (p-value $=0.001)$ but has no impact on course failure. Since students at flat-pricing schools do not bear the financial cost of enrolling in a course and withdrawing after the drop deadline, they appear to do so much more frequently. ${ }^{21}$ Finally, flat pricing is also associated with a modest but measurable 0.05 point lower grade-point-average, on a base of 3.08 ( $\mathrm{p}$-value = 0.01). In results not reported, we found that the additional courses students are induced to take in response to a subsidized marginal price are not substantively different than their typical courses and, if anything, are in the core subjects of Humanities/English and Social Science, seem to be degree-related, and that there is little systematic substitution from 3- to 4-credit courses. ${ }^{22}$ The effect on course performance suggests that students who have chosen larger credit loads may

\footnotetext{
${ }^{20}$ We also used the re-weighting approach described by DiNardo, Fortin, and Lemieux (1996) to construct counterfactuals of the entire distributions of credits attempted and earned, weighting students at per-credit schools to mirror the observable characteristics of students at flat-pricing institutions. This procedure produces very similar results: Marginal price has its largest effect on the likelihood of attempting up to 15 credits, but has a much more modest impact on the likelihood of earning credits. Furthermore, there are only small (and insignificant) differences in the distribution of credits attempted and earned by less-than-full-time students. These results are presented in Appendix C, Figure C3.

${ }^{21}$ Estimates from models that include UM-AA or do not control for institution-level ACT are similar.

${ }^{22}$ Results available from authors upon request. We characterize each course taken into one of 12 broad subject areas based on CIP codes (available at some institutions), academic department/subject, and/or course title. "Degreerelated" refers to CIP codes other than 31 through 37, which include Parks, Recreation, and Leisure Studies, Basic Skills/Remedial, Citizenship Activities, Health-related Knowledge and Skills, Interpersonal and Social Skills, Leisure and Recreational Activities, and Personal Awareness and Self-Improvement.
} 
perform worse because of too heavy a credit load. Since effort is not observed, we cannot fully identify the channel through which course performance is affected - but it does not appear to happen through a shift in the types of courses taken.

\section{Robustness}

Table 4 examines the robustness of our main findings to various changes in sample, specification, and controls. Our full sample includes all college students enrolled in 2011-2012, including students that have chosen to persist beyond the first year. This may introduce sample selection bias if marginal price influences persistence. In addition, marginal pricing could have greater (or lesser) effects for lower-classmen as their course-taking would be less driven by graduation requirements. Yet, estimates focused on just freshmen (2011 high school graduates) are quite similar (column 2) to the full sample for all outcomes. ${ }^{23}$

Having data on the full universe of students in public universities in the state permits us to control for individual characteristics quite flexibly. Estimates that include separate fixed effects for the large number of demographic groups defined by the six-way interaction of ACT score (each single point separately), female, race/ethnicity, FARM, LEP, and special education status (column 3) produces estimates that are nearly identical to our baseline specification.

We address the possibility that students may choose to attend flat-pricing institutions based on unobservable student characteristics in two complementary ways. High school fixed effects absorb any high-school-specific peer, background, or resource differences that may correlate with college choice and schooling intensity. Such within-school comparisons (column 4) are indistinguishable from the baseline specification. We also presents 2SLS estimates in which we instrument for flat pricing of institution attended with the pricing policy of the

\footnotetext{
${ }^{23}$ As reported in Appendix Table A2, estimates are quite similar for each cohort separately.
} 
university closest to a student's high school. Point estimates are qualitatively similar, but smaller in magnitude than base model estimates and with much larger p-values due to imprecision. ${ }^{24}$

Our base model controls for the midpoint of incoming students' ACT scores, as this variable is more highly correlated with freshman retention rates than other measures we considered, was inferred to be the least noisy proxy for college quality (Black and Smith, 2006), and is used extensively in the college quality literature. ${ }^{25}$ Given the small number of institutions, we are limited to including only a few institution-level covariates due to multicollinearity issues. That said, columns 6 to 8 of Table 4 additionally control for other institutional characteristics to address the possibility that institutions with flat pricing differ along other dimensions that also influence course-taking. Controlling for instructional and student services spending (in addition to institution-level ACT score) weakens our main findings (column 6), but specifications with admissions rate or number of full-time faculty per student are quite similar to our preferred model. Furthermore, estimates that do not control for any institutional characteristics (columns 1 and 4 in Table 2) are quite similar to these richer models.

Finally, we examine robustness to two alternative specifications for our main explanatory variable. A $\$ 100$ decrease in the marginal price of per additional credit is associated with a 2.2 percentage point increase in the likelihood of attempting more than 12 credits, a 1.8 percentage point increase in likelihood of withdrawing from a class, and a reduction in term GPA of 0.016, but no change in credits earned. These magnitudes are comparable to our base model given that the average, additional per-credit price (for credits above 12 ) is $\$ 281$ (e.g., $0.022 * 2.81=0.062$ ).

\footnotetext{
${ }^{24}$ The first-stage estimates are reported in Appendix Table A3. The first stage is of modest strength $(\mathrm{F}=13.2)$, though the p-values reported for the 2SLS specifications are from cluster-robust standard errors that do not account for the small number of clusters. By way of comparison, these 2SLS standard errors are twice as large as those from the base model estimates (also without accounting for the small number of clusters).

${ }^{25}$ Black and Smith (2006) do not consider spending per student as proxy variables, though do consider facultystudent ratios which are highly correlated with instructional spending per student. Appendix Table A4 reports correlations between different measures of institutional quality in our sample. ACT midpoint also tends to be positively associated with our outcomes, while results for other institutional characteristics are less consistent.
} 
This specification fully exploits the variation in marginal price across institutions, including the modest marginal price ( $\$ 80$ per credit above 12) charged by the Flint and Dearborn campuses of the University of Michigan, which our base specification ignores by characterizing them as "flat" institutions. Finally, results are generally robust to directly coding the UM-Flint and UMDearborn campuses as per-credit institutions, though estimated effects on credits earned are more positive in this specification.

\section{Heterogeneity}

Our theoretical framework suggests that students who would otherwise locate at the fulltime minimum of 12 credits would be most strongly affected by flat pricing. Such students experience only a substitution effect (non-school time has become more expensive) and are unambiguously predicted to increase their credit intensity. In fact, we should observe a "hole" in the density of students at the full-time minimum at flat-pricing schools if credit intensity were truly continuous. Since we cannot know the credit load that students at flat schools would choose when faced with linear pricing, we use students at per-credit schools with identical observed characteristics to form this counterfactual.

We begin with our sample of full-time students (i.e., those attempting at least the fulltime minimum of 12 credits). We then create a large number of mutually exclusive student groups defined by the six-way interaction of ACT score (each single point separately), female, race/ethnicity, FARM, LEP, and special education status. Within each of these groups we compare the credits attempted (earned) between students at per-credit and flat-pricing schools. Figure 5 shows these results graphically. ${ }^{26}$ Groups are ordered according to the average number of credits attempted (earned) at per-credit institutions so that those farthest left are the groups

\footnotetext{
${ }^{26}$ Figures are similar and the conclusions unchanged if we include part-time students in our sample for Figure 5.
} 
most likely to attempt (earn) close the full-time minimum. ${ }^{27}$ The vertical distance provides an estimate of the effect of flat pricing for each group. These comparisons are among very similar students (e.g., among black non-special-education non-LEP females who were eligible for free or reduced-price meals and scored a 23 on the ACT).

Consistent with the theory, we find estimated treatment effects on credits attempted are largest for students closest to the full-time minimum: students at flat schools attempt about one credit more, on average. Treatment effects diminish as we move up the distribution of average attempted credits. Effects on credits earned are even smaller and close to zero for all but the bottom third of groups. This suggests that our main results are indeed being driven by impacts on credits attempted for those students who would locate near the 12-credit threshold under a percredit pricing scheme. Students in the bottom 20 demographic subgroups in Figure 5 are overwhelmingly black (95\%); 30\% were eligible to receive free or reduced-price meals in high school. The typical student in this group had an ACT composite score of 17.5 and attempted 13.2 credits. Students in the top 20 demographic subgroups are non-black, mostly female (80\%) and non-FARM (only 5\% FARM), scored an average of 25.6 on the ACT, and attempted an average of 14.6 credits. $^{28}$

Rather than combine multiple sources of heterogeneity into one index, we also explored heterogeneity in our regression framework by explicitly contrasting effects by observable

\footnotetext{
${ }^{27}$ The $\mathrm{x}$-axis simply counts the number of student groups graphed where groups are ordered by the average credits taken in per-credit schools. Only groups containing at least 50 students in each type of school are shown in Figure 5, though the pattern is unchanged if more groups are included.

${ }^{28}$ In Appendix Table A5, we repeat our regression analysis separately by quintile of predicted credits attempted based on student characteristics with similar results. To construct quintiles we estimate a first-stage regression using data only on students at per-credit institutions where the outcome is credits attempted and the only covariates are student-level characteristics. We use coefficients from this model to predict the number of credits attempted for all students in our analytic sample and divide students in quintiles based on this prediction. Students in the bottom quintile are those closest to the 12-credit, full-time benchmark. Given recent concerns about the potential for this process to introduce systematic errors in the extremes of the prediction distribution, thereby biasing subgroup treatment effects (Abadie, Chingos, \& West, 2013), we only include subgroups with more than 50 students per cell in Figure 5. In addition, our main sample sizes are quite large, mitigating bias-causing errors due to over-fitting in this prediction-based approach to exploring heterogeneity (Abadie, Chingos, \& West, 2013, p. 4).
} 
characteristics, such as sex and eligibility for free or reduced-price meals. This heterogeneity analysis was motivated by evidence of differential effects of other interventions for women versus men (e.g., Anderson, 2008), the overtaking of men by women in college entry and completion (Goldin, Katz, \& Kuziemko, 2006), and the stronger response by low-income students to college prices relative to their more advantaged peers (Kane, 1994; Dynarski, 2002). These results (reported in Appendix Table A6) are largely consistent with the pattern depicted in Figure 5: effects of flat pricing remain concentrated along the margin of attempted (not earned) credits and withdrawal and are larger for low-income students. Though, in Table A6 there is suggestive evidence that a subset of FARM and female students may translate a small share of additional attempted credits into earned ones. These are likely to be high-achieving FARM and female students, given the results in Table A5 (wherein we see a slight increase in the effect of flat pricing on credits earned for students at the top of the distribution of predicted average credits attempted). Still, for these two subgroups, the coefficients on the likelihood of earning more than 12 credits are always half the magnitude (or less) of the corresponding coefficients on the likelihood of attempting more than 12 credits - mitigated by the consistent effect of flat pricing on course withdrawal.

\section{E. Long-term Outcomes}

We now explore the impact of marginal pricing on the longer-term outcomes of persistence and credit accumulation. We track entry into and persistence through postsecondary education using the National Student Clearinghouse (NSC). For each member of the high school cohorts of 2008 through 2011, we identify students (of any intensity) that enrolled in a Michigan public 4-year university in the fall term immediately following high school graduation 
(excluding the University of Michigan-Ann Arbor). ${ }^{29}$ Figure 6 plots the fraction of these students enrolled in any college (Panel A) or a MI public 4-year university (Panel B) over time, separately by the pricing policy of the first institution attended. Across all institutions, 96\% of students attend any college (including Michigan universities, community colleges, and private colleges) in their second semester, though enrollment drops to $81 \%$ by the start of the fourth academic year. Comparable rates for enrollment at a Michigan public university are $93 \%$ and $70 \%$, respectively.

With the University of Michigan-Ann Arbor excluded, rates of persistence beyond the first year at any college or a Michigan public university appear slightly higher for students starting at institutions with per-credit (rather than flat) pricing practices. ${ }^{30}$ These raw persistence patterns do not control for the characteristics of students. When we control for such traits (Table 5), these patterns remain largely unchanged, though smaller in magnitude. In no case do we find statistically significant differences in persistence patterns of students at flat-pricing colleges compared to their observationally identical counterparts who start at per-credit-pricing institutions, though coefficients are mostly small and always negative.

We now directly examine impacts on credits accumulated over several years. Recall that STARR data contain information about all courses taken in 2011-2012 and in all prior terms, among students still enrolled in the 2011-2012 academic year. Thus for all students in the 2008, 2009, and 2010 cohorts that persist to 2011-2012, we calculate cumulative credits attempted and earned as of Spring 2012. We make two important sample restrictions. First, we restrict our

\footnotetext{
${ }^{29}$ Very few students enter one of these institutions in the spring term, so the fall enrollment restriction is not too binding. Students that delay entry into or eventually transfer to a Michigan public university from private or community colleges are also excluded to ensure that the sample is similar across cohorts, given that later cohorts would mechanically have few delayed or transfer entrants.

${ }^{30}$ Figure C4 in Appendix C plots persistence rates separately by cohort and pricing policy. Note that the persistence gap between per-credit and flat schools is almost entirely driven by the 2008 high school cohort. Gaps by pricing policy are minimal for the other cohorts.
} 
analysis to students enrolled (at least part time) in any Michigan public 4-year college in all fall and spring semesters since high school graduation (as indicated by the NSC), excluding

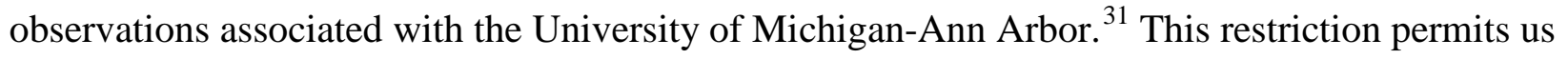
to abstract from students’ decisions to persist and instead focus on credits accumulated among those that have decided to persist in all periods. ${ }^{32}$ Second, we only keep students with complete consistency between their NSC and STARR records. ${ }^{33}$ This restriction assures we accumulate all credits attempted and earned by an individual. ${ }^{34}$

In Table 6 we analyze cumulative credits attempted, cumulative credits earned, and whether cumulative credits earned are above the threshold for on-time, all as of Spring 2012. Since these on-time thresholds differ by student level (sophomore, junior, senior), we present estimates separately by cohort. Overall, we find little evidence that flat pricing encourages students to attempt or accumulate more credits over time. On average, students have attempted 59.0 credits and earned 54.5 by the end of their second year in college, but there is little difference between students at per-credit and flat-pricing institutions. Nor are students at flat institutions more likely to have earned 60 credits, a marker for graduating within four years. ${ }^{35}$ Results for the 2009 and 2008 cohorts are qualitatively similar: the typical student is attempting and earning fewer credits than the on-time benchmark and there is minimal difference between students at flat and per-credit schools. Any modest average attempted credit advantage seen

\footnotetext{
${ }^{31}$ So members of the high school class of 2008 (2009, 2010) must be enrolled in a MI public university for all 8 (6, 4) fall and spring terms since high school graduation.

${ }^{32}$ Further, our intention is to construct markers of on-time credit accumulation that are only relevant for students that have already chosen to enroll. Given the minimal impact on persistence, we do not believe this restriction creates grave concerns about sample selection bias.

${ }^{33}$ Though NSC-STARR consistency is quite high in the 2011-2012 academic year (98\%, similar for flat and percredit schools), it deteriorates in earlier years and becomes slightly worse at per-credit institutions. Thus results for the 2008 and 2009 cohorts that rely on historical data (such as cumulative credits) should be interpreted with some caution.

${ }^{34}$ We find similar effects on credits attempted in 2011-2012 with this restricted sample as with the full sample reported earlier. These results are available from the authors upon request.

${ }^{35}$ Though not reported in the table, we find similar results for cumulative credits across fall and spring terms only (excluding summer).
} 
among students at flat pricing institutions is greatly reduced when looking at credits earned. These patterns of minimal impact of marginal price on cumulative credits attempted or earned and persistence are robust to various sample restrictions, methods for addressing non-random student sorting (group FEs, high school FEs), and controls for different institutional characteristics. ${ }^{36}$

\section{Discussion and Conclusions}

Using rich administrative data on all in-state students at the 15 public universities in Michigan, this paper provides the first evidence on whether students' educational investments respond to marginal price incentives. We find that a zero marginal price (above the full-time minimum) compels about 7 percent of students to attempt about one class more (i.e., up to 3 additional credits). Yet, additional attempted credits do not appear to translate into more credits earned in a semester or cumulatively, greater persistence, or reduced time-to-degree, though estimates of these outcomes are admittedly less precise and more variable across specifications. This apparent wedge between credits attempted and earned is due to the increased propensity of students exposed to flat pricing to withdraw from classes. Further, flat pricing is associated with a small, but measurable and robust, 0.05 point reduction in semester GPA.

Institutions have voiced divergent views about the likely effects of marginal price. Some have reduced the marginal price to zero in order to encourage students to "Finish in Four," as Adam’s State's plan is called. Others see per-credit pricing as an equitable way of generating revenue from students who consume more resources; in this vein "flat" pricing is viewed as a subsidy to students who would have taken large course loads anyway. Our findings support this latter interpretation, suggesting that increases in marginal price may be a non-distortionary way for institutions to raise revenue. Additional revenue could be used to finance other interventions

\footnotetext{
${ }^{36}$ These results are reported in Appendix Table A7.
} 
with a stronger track record of improving student success, to increase financial aid, or possibly to lower the average tuition price faced by students taking lower credit loads.

Our finding that incremental pricing has minimal impacts on credit-taking and achievement stands in contrast to the rather large literature that documents substantial student responses to price in other choice environments, such as the decision to enroll in college. Yet, the postsecondary environment in which students encounter marginal prices differs in a number of ways from the setting in which students make choices about college-going. Our theoretical extensions describe various reasons why we might expect responses to marginal price to be muted in the context of higher education. Our results are consistent with the presence of substantial adjustment frictions, large or uncertain marginal effort costs, or large nonlinear returns to degrees. All of these would dampen the effects of marginal price on student coursetaking or cause the effects on attempted versus earned credits to diverge. Policies designed with large student price elasticities in mind (informed by the enrollment and college choice literature) may not translate well to the goal of supporting and hastening student progress with marginal incentives.

Another explanation for the limited effects of marginal price on college outcomes is that marginal pricing policies may simply be less salient than the overall (average) price, which determines enrollment and college choice. In Michigan, we see some variation in the salience of pricing policies (and their relation to cost savings and time-to-degree) across institutions. For example, Lake Superior State University exclaims in large, bold font at the top of its webpage on costs: "LSSU offers a flat tuition rate for those taking 12 to 17 credits. This means you can take 17 credit hours for the price of 12 , a savings of over $\$ 4,100$ per year, and over $\$ 16,400$ in four 
years! ${ }^{37}$ Other colleges simply state the overall or per-credit tuition prices, sometimes buried in tables on registrar webpages. Lastly, students may respond to some other feature of price than marginal price, such as average or expected marginal price, as has been observed in other settings (Ito, 2013).

Our study has several limitations that future work should address. Though our setting and analyses control for many possible confounders, we cannot entirely rule out differences in institutional characteristics as a source of bias. Examining the experience of institutions that have recently changed their marginal price is a promising strategy for addressing this type of bias. The main results also suggest a need to dig deeper into the choices students make after entering college to better understand the mechanisms at work. A task for future work is to separate competing explanations, possibly through an experimental information intervention along the lines of Chetty and Saez (2013). Finally, there are several other possible effects of marginal price we have not yet explored: major choice, financial burden, and interest exploration. These too are important questions for future research.

${ }^{37}$ Source: http://www.lssu.edu/costs/ 


\section{REFERENCES}

Abadie, A., Chingos, M. M., \& West. M. R. (2013). Endogenous stratification in randomized experiments. NBER Working Paper No. 19742.

Anderson, M. L. (2008). Multiple inference and gender differences in the effects of early intervention: A reevaluation of the Abecedarian, Perry Preschool, and Early Training projects. Journal of the American Statistical Association, 103(484), 1481-1495.

Angrist, J., Lang, D., \& Oreopoulos, P. (2009). Incentives and services for college achievement: Evidence from a randomized trial. American Economic Journal: Applied Economics, 1(1), 136-163.

Baum, S., Conklin, K., \& Johnson, N. (2013, November 12). Stop penalizing poor college students. New York Times, Opinion.

Baum, S., McDemmond, M., \& Jones, G. (2014, July). Institutional Strategies for Increasing Affordability and Success for Low-Income Students in the Regional Public Four-Year Sector: Tuition and Financial Aid. Accessed 10/16/2014 at http://hcmstrategists.com/maximizingresources/images/Tuition_Paper.pdf

Bettinger, E. (2004). How Financial Aid Affects Persistence. In College Choices: The Economics of Where to Go, When to Go, and How to Pay for It, ed. Caroline Hoxby. University of Chicago Press.

Bitler, M. P., \& Karoly, L. A. (2015). Intended and Unintended Effects of the War on Poverty: What Research Tells Us and Implications for Policy. Journal of Policy Analysis and Managmeent. 34 (3): 639-696.

Black, D. and J. Smith (2006). Estimating the Returns to College Quality with Multiple Proxies for Quality. Journal of Labor Economics, 24(3), 701-728.

Bound, J., Lovenheim, M. F., \& Turner, S. (2012). Increasing time to Baccalaureate degree in the United States. Education Finance and Policy, 7(4), 375-242.

Bound, J., Lovenheim, M. F., \& Turner, S. (2010). Increasing time to Baccalaureate degree in the United States. NBER Working Paper Series, No. 15982.

Borenstein, S. (2012). The Redistributional Impact of Nonlinear Electricity Pricing. American Economic Journal: Economic Policy, 4(3), 56-90.

Cameron, A. C., Gelbach, J. B., \& Miller, D. L. (2008). Bootstrap-based improvements for inference with clustered errors. Review of Economics and Statistics, 90(3), 414-427. 
Castleman, B. L. and Long, B. T.. (2013). Looking Beyond Enrollment: The Causal Effect of Need-Based Grants on College Access, Persistence, and Graduation. NBER Working Paper No. 19306

Chetty, R., Friedman, J., Olsen, T., \& Pistaferri, L. (2011). Adjustment Costs, Firm Responses, and Micro vs. Macro Labor Supply Elasticities: Evidence from Danish Tax Records. Quarterly Journal of Economics, 126, 749-804.

Chetty, R., \& Saez, E. (2013). Teaching the Tax Code: Earnings Responses to an Experiment with EITC Recipients. American Economic Journal: Applied Economics, 5(1), 1-31.

Cornell Higher Education Research Institute. (2011). 2011 Survey of Differential Tuition at Public Higher Education Institutions.

Access: http://www.ilr.cornell.edu/cheri/upload/2011CHERISurveyFinal0212.pdf

Cornwell, C., Hee Lee, K., \& Mustard, D. B. (2005). Student responses to merit scholarship retention rules. Journal of Human Resources, 40(4), 987-917.

DesJardins, S., \& McCall, B. (2010). Simulating the effects of financial aid packages on college student stopout, reenrollment spells, and graduation chances. The Review of Higher Education, 33(4), 513-541.

DiNardo, J., Fortin, N. M., \&Lemieux, T. (1996). Labor market institutions and the distribution of wages, 1973-1992: A semiparametric approach. Econometrica, 64(5), 1001-1044.

Dynarski, S. M., Hemelt, S. W., \& Hyman, J. (2015). The missing manual: Using National Student Clearinghouse data to track postsecondary outcomes. Educational Evaluation and Policy Analysis, 37(1S), 53S-79S.

Dynarski, S. (2008). Building the stock of college-educated labor. Journal of Human Resources, 43(3), 576-610.

Dynarski, S. (2003). Does aid matter? Measuring the effect of student aid on college attendance and completion. American Economic Review, 93(1), 278-288.

Dynarski, S. (2002). The behavioral and distributional implications of aid for college. American Economic Review, 92(2), 279-285.

Ehrenberg, R. G. (2012). American higher education in transition. Journal of Economic Perspectives, 26(1), 193-216.

Friedberg, L. (2000). The Labor Supply Effects of the Social Security Earnings Test. Review of Economics and Statistics, 82(1), 48-63. 
Garibaldi, P., Giavazzi, F., Ichino, A., \& Rettore, E. (2012). College cost and time to complete a degree: Evidence from tuition discontinuities. Review of Economics and Statistics, 94(3), 699-711.

Goldin, C., Katz, L. F., Kuziemko, I. (2006). The homecoming of American college women: The reversal of the college gender gap. Journal of Economic Perspectives, 20(4), 133-156.

Goldrick-Rab, S., Harris, D. N, Benson, J., \& Kelchen, R. (2011). Conditional Cash Transfers and College Persistence: Evidence from a Randomized Need-Based Grant Program. Institute for Research on Poverty Discussion Paper no. 1393-11

Hemelt, S. W., \& Marcotte, D. E. (2011). The Impact of Tuition Increases on Enrollment at Public Colleges and Universities. Educational Evaluation and Policy Analysis, 33(4), 435-457.

Hemelt, S. W., \& Marcotte, D. E. (2015). The Changing Landscape of Tuition and Enrollment in American Public Higher Education. Unpublished Working Paper. University of North Carolina at Chapel Hill.

Hausman, J. A. (1981). “Labor Supply.” In How Taxes Affect Economic Behavior, ed. Henry J. Aaron and Joseph A. Pechman, 27-71. Washington, DC: Brookings Institution.

Hausman, J. A. (1985). Taxes and Labor Supply. In Handbook of Public Economics, Vol. I, ed Alan Auerbach and Martin Feldstein. Elsevier Science Publishers (North-Holland)

Ito, K.. (2013). How Do Consumers Respond to Nonlinear Pricing ? Evidence from Household Water Demand. Working Paper, Stanford University.

Ito, K.. (2014). Do Consumers Respond to Marginal or Average Price? Evidence from Nonlinear Electricity Pricing. American Economic Review, 104(2), 537-63.

Jacob, B., McCall, B. P., \& Stange, K. (2013). College as Country Club: Do Colleges Cater to Students' Preferences for Consumption? NBER Working Paper No. 18745. January 2013.

Kane, T. J. (2006). Public Intervention in Postsecondary Education, In Eric Hanushek and Finis Welch (eds.) Handbook on the Economics of Education, Amsterdam: Elsevier/NorthHolland.

Kane, T. J. (1994). College entry by blacks sine 1970: The role of college costs, family background, and the returns to education. Journal of Political Economy, 102(5), 878-911.

Kim, J. \& Stange, K. (2015). Pricing and University Autonomy: The Case of Tuition Deregulation in Texas. Unpublished working paper. University of Michigan. 
Kowalski, A. (2012). Estimating the Tradeoff Between Risk Protection and Moral Hazard with a Nonlinear Budget Set Model of Health Insurance. NBER Working Paper 18108.

Lewin, T. (2013, August 22). Obama’s plan aims to lower college costs. New York Times, Education, p. A1.

Long, B. T. (2004). How Have College Decisions Changed Over Time? An Application of the Conditional Logistic Choice Model. Journal of Econometrics, 121, 271-298.

Miller, C., Binder, M., Harris, V., \& Krause, K. (2011). Staying on track: Early findings from a performance-based scholarship program at the University of New Mexico. MDRC Report.

Moffitt, R. (1990). The economics of kinked budget constraints. Journal of Economic Perspectives. 4(2): 119-139.

Mumper, M. (2012, November 21). Improving college productivity with a full course-load. Denver Post, Access: http://blogs.denverpost.com/opinion/2012/11/21/improvingcollege-productivity-full-courseload/29384/

National Conference of State Legislatures (2010). Improving College Completion: Action Steps for Legislators, Access: http://www.ncsl.org/issues-research/educ/improving-collegecompletion-action-steps-for-le.aspx

Olmstead, S. M., Hanemann, M. W. \& Stavins, R. N. (2007). Water demand under alternative price structures. Journal of Environmental Economics and Management, 54(2), 181-198.

Presidents Council, State Universities of Michigan (2011). Reports on Tuition and Fees, Access: http://www.pcsum.org/ReportsandStudies/PCSUMReportsandStudies/TuitionandFeesRe ports/tabid/79/Default.aspx

Richburg-Hayes, L., Cha, P., Cuevas, M., Grossman, A., Patel, R., \& Sommo, C. (2009). Paying for college success. MDRC Policy Brief.

Saez, E., Slemrod, J. B., \& Giertz, S. H. (2012). The elasticity of taxable income with respect to marginal tax rates: A critical review. Journal of Economic Literature, 50(1), 3-50.

Saez, E. (2010). Do Taxpayers Bunch at Kink Points? American Economic Journal: Economic Policy, 2(3), 180-212.

Scott-Clayton, J. (2010). On money and motivation: A quasi-experimental analysis of financial incentives for college achievement. Journal of Human Resources, 46(3), 614-646.

Shapiro et al., (2013). Completing college: A state-level view of student attainment rates. National Student Clearinghouse Research Center, Signature Report \#4. 
Stange, K. (2012). An Empirical Investigation of the Option Value of College Enrollment. American Economic Journal: Applied Economics, 4(1), 49-84.

Stange, K. (2015). Differential Pricing in Undergraduate Education: Effects on Degree Production by Field. Journal of Policy Analysis and Management. 34(1): 107-135.

Tuner, S. (2004). Going to College and Finishing College: Explaining Different Educational Outcomes. In College Decisions: How Students Actually Make Them and How They Could, ed. Caroline Hoxby. University of Chicago Press for NBER. 
Figure 1. Sticker Price for Four Michigan Public Universities, Fall 2011

First-time, in-state students in non-differentiated programs
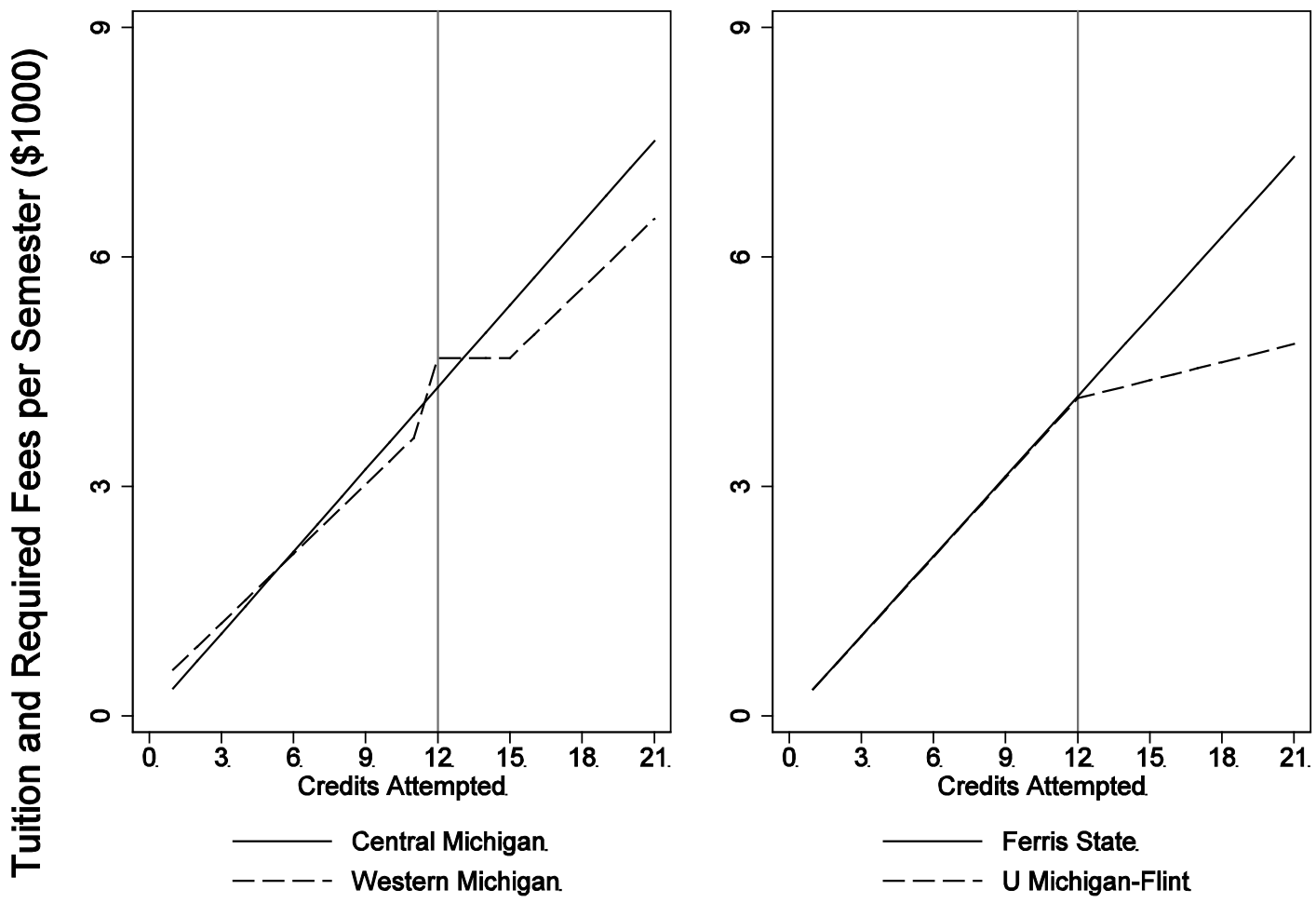

Source: Presidents Council, State Universities of Michigan, Report on Tuition and Fees 2011-2012. 


\section{Figure 2. Single-Period School Intensity Budget Constraint}

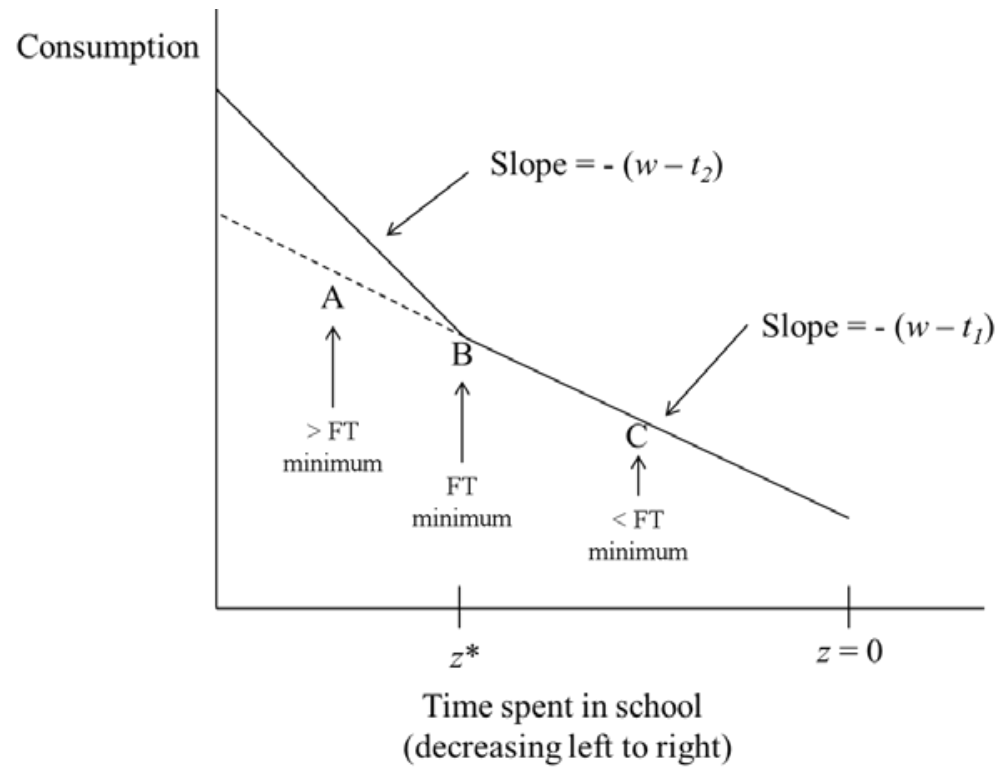

Notes: Figure plots non-linear budget constraint (solid) for choice of school intensity if earnings increase linearly with intensity and per-credit tuition price is reduced (from $t_{1}$ to $t_{2}$ ) for intensity greater than $\mathrm{z}^{*}$. Linear budget constraint (dashed) is shown for reference. 
Figure 3. ACT Score Ranges at Michigan Public Universities, by Pricing Policy

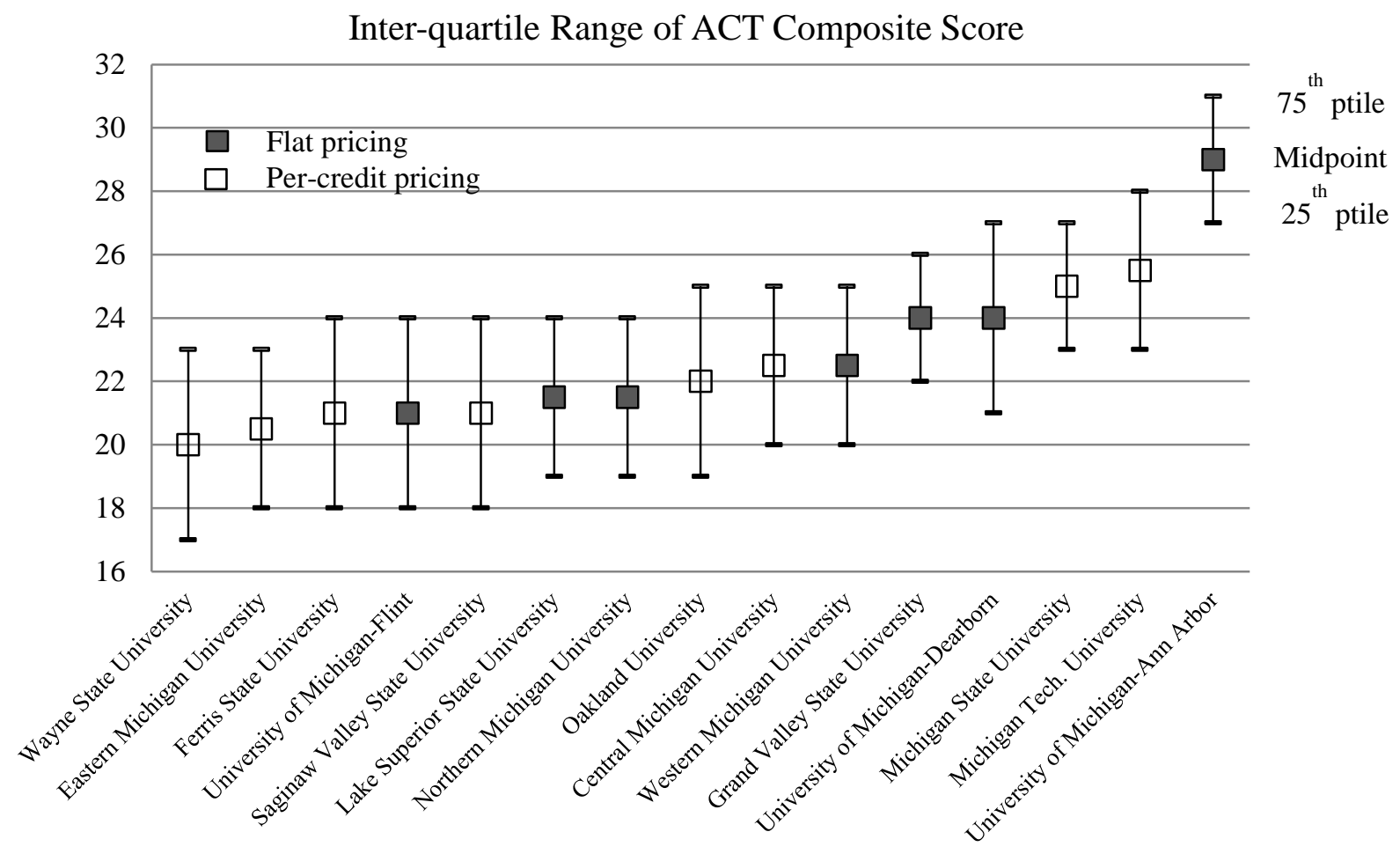

Source: Integrated Postsecondary Education Data System (IPEDS), data for 2009-2010 incoming class. 
Figure 4. Fraction of Students at or above Credit Threshold at Michigan Public Universities

\section{A. Credits Attempted}

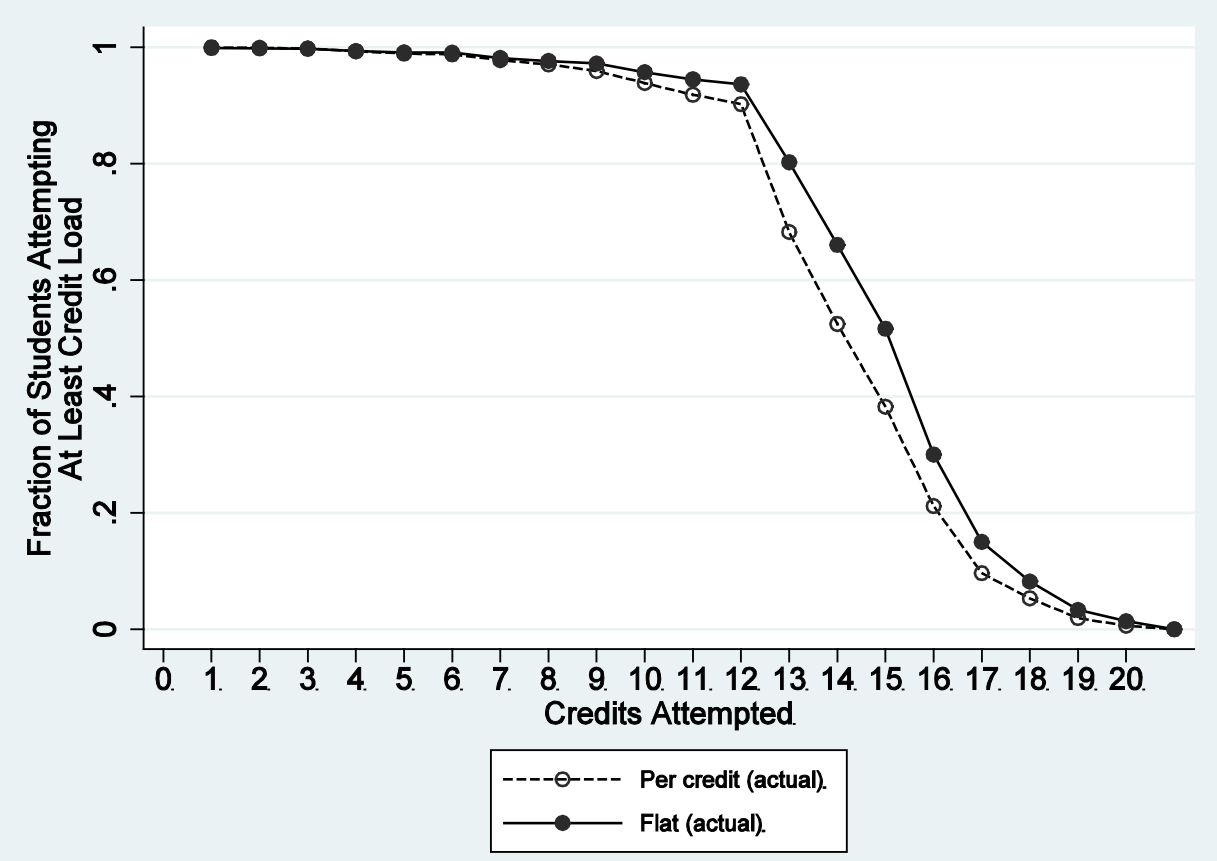

B. Credits Earned

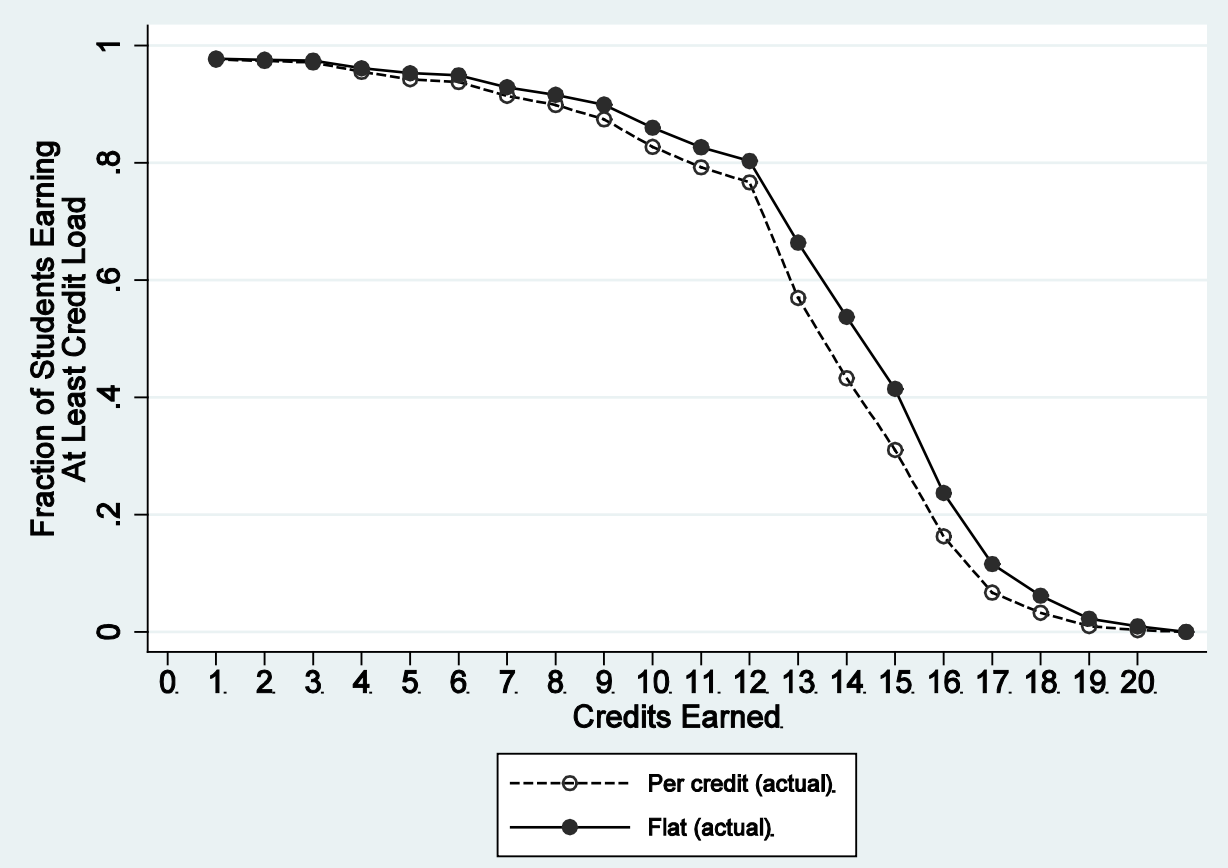

Notes: Figure plots the fraction of students at Michigan public universities that attempt (or earn) at least X credits in the semester, separately by the pricing structure of the university. Sample includes college-going Michigan high school graduates form the classes of 2008 through 2011. Credit-taking is observed in the fall and spring of the 20112012 academic year. 


\section{Figure 5. Heterogeneous Effects of Flat Pricing by Student Characteristics}

\section{A. Credits Attempted}
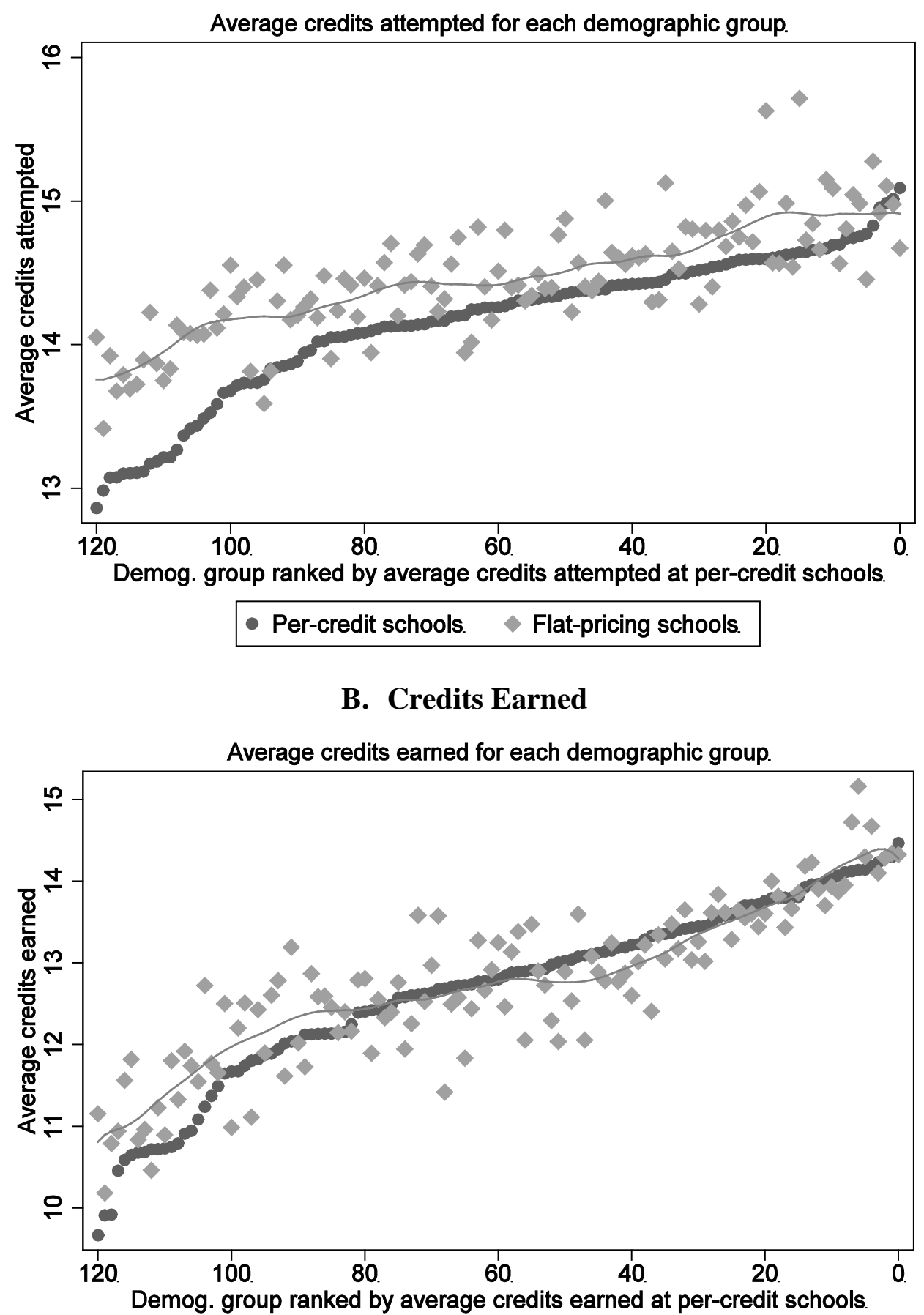

- Per-credit schools $\diamond$ Flat-pricing schools

Notes: Each demographic group is defined by a six-way interaction between ACT score, female, race/ethnicity, FARM, LEP, and special education status. Sample is limited to full-time students and excludes the University of Michigan-Ann Arbor. Only those groups containing at least 50 students are shown. Credit-taking is observed in the fall and spring of the 2011-2012 academic year. See text for additional details. 
Figure 6. Persistence Among Fall Enrollees at MI Public Universities, by Pricing Policy of First Institution Attended

A. Persistence at Any College

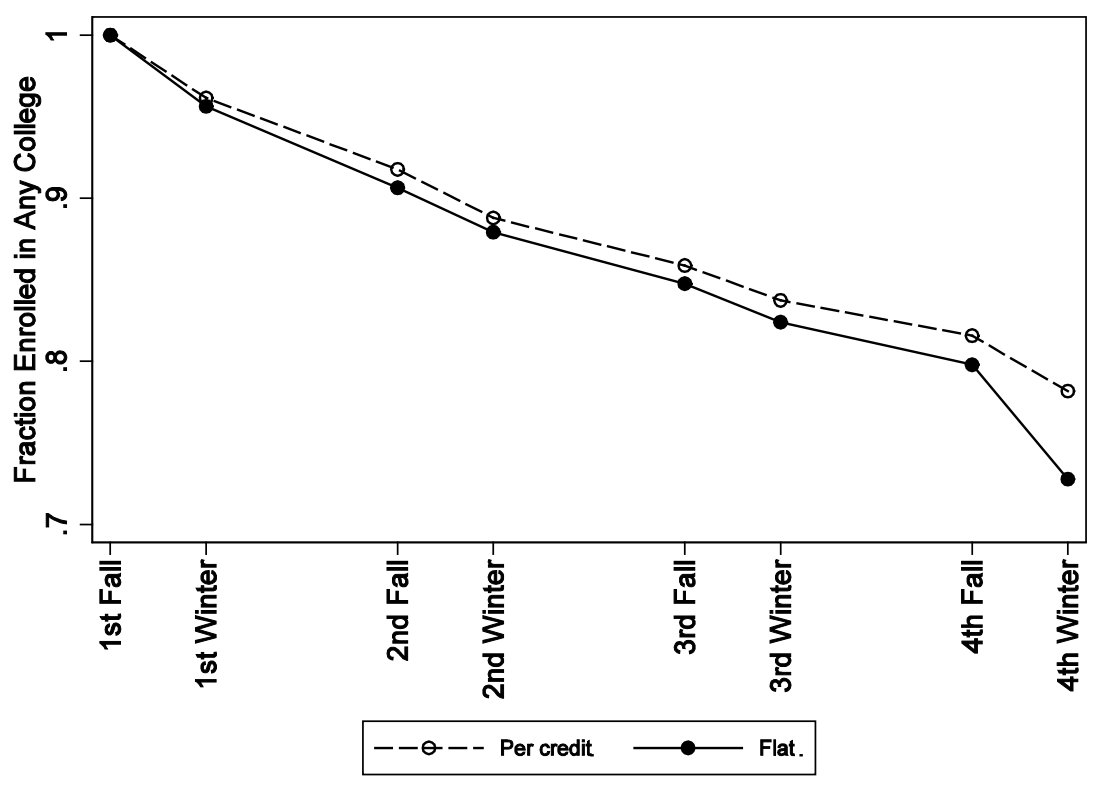

B. Persistence at Any MI Public 4-year University

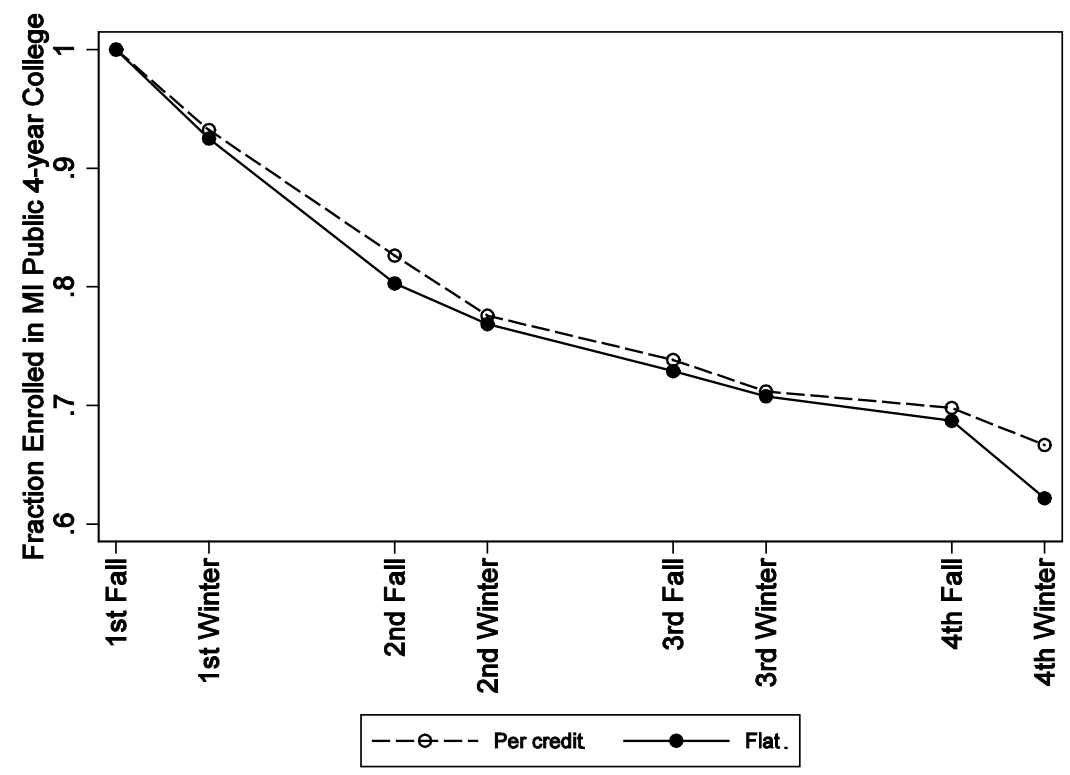

Notes: Figures plot the fraction of students enrolled in any college (Panel A) or a MI public university separately by pricing policy of first institution attended. Underlying sample is restricted to MI public high school graduates from 2008 to 2011 that enrolled in a MI public 4-year university in the fall immediately after high school, excluding University of Michigan-Ann Arbor. 
Table 1. Student Sample Characteristics, by Marginal Pricing Practice 2008-2011 High School Graduates

\begin{tabular}{|c|c|c|c|c|c|}
\hline & \multirow[b]{2}{*}{$\begin{array}{c}\text { Per-credit } \\
\text { schools (PC) }\end{array}$} & \multicolumn{2}{|c|}{ Include all flat schools } & \multicolumn{2}{|c|}{ Exclude UM-Ann Arbor } \\
\hline & & $\begin{array}{c}\text { Flat schools } \\
\text { (F) }\end{array}$ & $\begin{array}{c}\text { Difference } \\
\text { (F - PC) }\end{array}$ & $\begin{array}{c}\text { Flat schools } \\
(\mathrm{F})\end{array}$ & $\begin{array}{c}\text { Difference } \\
\text { (F - PC) }\end{array}$ \\
\hline \multicolumn{6}{|c|}{ A. Demographic and Achievement Characteristics } \\
\hline Female & $\begin{array}{c}0.554 \\
(0.497)\end{array}$ & $\begin{array}{c}0.549 \\
(0.498)\end{array}$ & $\begin{array}{l}-0.005 \\
(0.002)\end{array}$ & $\begin{array}{c}0.560 \\
(0.496)\end{array}$ & $\begin{array}{c}0.006 \\
(0.002)\end{array}$ \\
\hline Black & $\begin{array}{c}0.118 \\
(0.322)\end{array}$ & $\begin{array}{c}0.074 \\
(0.261)\end{array}$ & $\begin{array}{l}-0.044 \\
(0.001)\end{array}$ & $\begin{array}{c}0.079 \\
(0.269)\end{array}$ & $\begin{array}{l}-0.039 \\
(0.002)\end{array}$ \\
\hline Hispanic & $\begin{array}{c}0.016 \\
(0.125)\end{array}$ & $\begin{array}{c}0.021 \\
(0.142)\end{array}$ & $\begin{array}{c}0.005 \\
(0.001)\end{array}$ & $\begin{array}{c}0.022 \\
(0.146)\end{array}$ & $\begin{array}{c}0.006 \\
(0.001)\end{array}$ \\
\hline Other & $\begin{array}{c}0.040 \\
(0.197)\end{array}$ & $\begin{array}{c}0.062 \\
(0.241)\end{array}$ & $\begin{array}{c}0.022 \\
(0.001)\end{array}$ & $\begin{array}{c}0.033 \\
(0.180)\end{array}$ & $\begin{array}{l}-0.007 \\
(0.001)\end{array}$ \\
\hline White & $\begin{array}{c}0.826 \\
(0.379)\end{array}$ & $\begin{array}{c}0.843 \\
(0.363)\end{array}$ & $\begin{array}{c}0.018 \\
(0.002)\end{array}$ & $\begin{array}{c}0.866 \\
(0.340)\end{array}$ & $\begin{array}{c}0.040 \\
(0.002)\end{array}$ \\
\hline FARM & $\begin{array}{c}0.069 \\
(0.254)\end{array}$ & $\begin{array}{c}0.058 \\
(0.234)\end{array}$ & $\begin{array}{l}-0.011 \\
(0.001)\end{array}$ & $\begin{array}{c}0.069 \\
(0.254)\end{array}$ & $\begin{array}{c}0.000 \\
(0.001)\end{array}$ \\
\hline LEP & $\begin{array}{c}0.038 \\
(0.191)\end{array}$ & $\begin{array}{c}0.035 \\
(0.183)\end{array}$ & $\begin{array}{l}-0.003 \\
(0.001)\end{array}$ & $\begin{array}{c}0.028 \\
(0.165)\end{array}$ & $\begin{array}{l}-0.010 \\
(0.001)\end{array}$ \\
\hline Special Education & $\begin{array}{c}0.066 \\
(0.248)\end{array}$ & $\begin{array}{c}0.063 \\
(0.243)\end{array}$ & $\begin{array}{l}-0.003 \\
(0.001)\end{array}$ & $\begin{array}{c}0.074 \\
(0.261)\end{array}$ & $\begin{array}{c}0.008 \\
(0.001)\end{array}$ \\
\hline ACT composite (student) & $\begin{array}{l}22.096 \\
(4.193)\end{array}$ & $\begin{array}{l}23.612 \\
(4.661)\end{array}$ & $\begin{array}{c}1.514 \\
(0.020)\end{array}$ & $\begin{array}{l}21.909 \\
(3.896)\end{array}$ & $\begin{array}{l}-0.187 \\
(0.020)\end{array}$ \\
\hline \multicolumn{6}{|c|}{ B. College Characteristics (enrollment-weighted) } \\
\hline In-state tuition and fees (sticker price) & $\begin{array}{l}10,682 \\
(1,663)\end{array}$ & $\begin{array}{l}10,592 \\
(1,873)\end{array}$ & $\begin{array}{l}-89 \\
(8)\end{array}$ & $\begin{array}{l}9,408 \\
(444)\end{array}$ & $\begin{array}{c}-1,274 \\
(7)\end{array}$ \\
\hline Instructional spending per FTE & $\begin{array}{c}9,699 \\
(3,022)\end{array}$ & $\begin{array}{l}11,153 \\
(6,254)\end{array}$ & $\begin{array}{c}1,454 \\
(20)\end{array}$ & $\begin{array}{l}7,153 \\
(988)\end{array}$ & $\begin{array}{c}-2,546 \\
(13)\end{array}$ \\
\hline Student services spending per FTE & $\begin{array}{l}1,135 \\
(435)\end{array}$ & $\begin{array}{l}1,510 \\
(340)\end{array}$ & $\begin{array}{r}375 \\
(2)\end{array}$ & $\begin{array}{l}1,311 \\
(170)\end{array}$ & $\begin{array}{l}176 \\
(2)\end{array}$ \\
\hline Full-time faculty per $100 \mathrm{FTE}$ & $\begin{array}{c}5.009 \\
(1.524)\end{array}$ & $\begin{array}{c}7.338 \\
(4.447)\end{array}$ & $\begin{array}{c}2.329 \\
(0.013)\end{array}$ & $\begin{array}{c}4.478 \\
(0.407)\end{array}$ & $\begin{array}{l}-0.532 \\
(0.006)\end{array}$ \\
\hline Admissions rate & $\begin{array}{c}0.729 \\
(0.058)\end{array}$ & $\begin{array}{c}0.677 \\
(0.187)\end{array}$ & $\begin{array}{l}-0.052 \\
(0.001)\end{array}$ & $\begin{array}{c}0.789 \\
(0.081)\end{array}$ & $\begin{array}{l}0.061 \\
0.000\end{array}$ \\
\hline ACT composite (institution) & $\begin{array}{l}22.983 \\
(1.935)\end{array}$ & $\begin{array}{l}24.954 \\
(3.294)\end{array}$ & $\begin{array}{c}1.971 \\
(0.011)\end{array}$ & $\begin{array}{l}22.854 \\
(0.594)\end{array}$ & $\begin{array}{l}-0.129 \\
(0.008)\end{array}$ \\
\hline \multicolumn{6}{|l|}{ C. College Outcomes } \\
\hline Credits Attempted & $\begin{array}{l}13.752 \\
(2.821)\end{array}$ & $\begin{array}{l}14.399 \\
(2.778)\end{array}$ & $\begin{array}{c}0.779 \\
(0.012)\end{array}$ & $\begin{array}{l}14.058 \\
(2.639)\end{array}$ & $\begin{array}{c}0.306 \\
(0.014)\end{array}$ \\
\hline Credits Earned & $\begin{array}{l}12.491 \\
(3.808)\end{array}$ & $\begin{array}{l}13.274 \\
(3.883)\end{array}$ & $\begin{array}{c}0.787 \\
(0.017)\end{array}$ & $\begin{array}{l}12.588 \\
(3.935)\end{array}$ & $\begin{array}{c}0.097 \\
(0.019)\end{array}$ \\
\hline Attempt at least 12 credits & $\begin{array}{l}0.904 \\
(0.295)\end{array}$ & $\begin{array}{c}0.937 \\
(0.242)\end{array}$ & $\begin{array}{c}0.036 \\
(0.001)\end{array}$ & $\begin{array}{c}0.925 \\
(0.263)\end{array}$ & $\begin{array}{c}0.021 \\
(0.001)\end{array}$ \\
\hline Earn at least 12 credits & $\begin{array}{l}0.769 \\
(0.421)\end{array}$ & $\begin{array}{c}0.814 \\
(0.389)\end{array}$ & $\begin{array}{c}0.029 \\
(0.002)\end{array}$ & $\begin{array}{c}0.762 \\
(0.426)\end{array}$ & $\begin{array}{l}-0.008 \\
(0.002)\end{array}$ \\
\hline Attempt more than 12 credits & $\begin{array}{c}0.688 \\
(0.463)\end{array}$ & $\begin{array}{c}0.803 \\
(0.398)\end{array}$ & $\begin{array}{c}0.121 \\
(0.002)\end{array}$ & $\begin{array}{c}0.773 \\
(0.419)\end{array}$ & $\begin{array}{c}0.085 \\
(0.002)\end{array}$ \\
\hline Earn more than 12 credits & $\begin{array}{c}0.574 \\
(0.494)\end{array}$ & $\begin{array}{c}0.674 \\
(0.469)\end{array}$ & $\begin{array}{c}0.091 \\
(0.002)\end{array}$ & $\begin{array}{c}0.607 \\
(0.488)\end{array}$ & $\begin{array}{c}0.033 \\
(0.002)\end{array}$ \\
\hline Attempt 15 or more credits & $\begin{array}{c}0.391 \\
(0.488)\end{array}$ & $\begin{array}{c}0.513 \\
(0.500)\end{array}$ & $\begin{array}{c}0.135 \\
(0.002)\end{array}$ & $\begin{array}{c}0.469 \\
(0.499)\end{array}$ & $\begin{array}{c}0.078 \\
(0.002)\end{array}$ \\
\hline Earn 15 or more credits & $\begin{array}{c}0.316 \\
(0.465)\end{array}$ & $\begin{array}{c}0.421 \\
(0.494)\end{array}$ & $\begin{array}{c}0.111 \\
(0.002)\end{array}$ & $\begin{array}{c}0.354 \\
(0.478)\end{array}$ & $\begin{array}{c}0.038 \\
(0.002)\end{array}$ \\
\hline Withdraw from at least one class & $\begin{array}{c}0.091 \\
(0.288)\end{array}$ & $\begin{array}{c}0.128 \\
(0.334)\end{array}$ & $\begin{array}{c}0.036 \\
(0.001)\end{array}$ & $\begin{array}{c}0.152 \\
(0.359)\end{array}$ & $\begin{array}{c}0.061 \\
(0.002)\end{array}$ \\
\hline Fail at least one class & $\begin{array}{c}0.131 \\
(0.337)\end{array}$ & $\begin{array}{c}0.111 \\
(0.315)\end{array}$ & $\begin{array}{l}-0.020 \\
(0.001)\end{array}$ & $\begin{array}{c}0.130 \\
(0.336)\end{array}$ & $\begin{array}{l}-0.001 \\
(0.002)\end{array}$ \\
\hline Term GPA & $\begin{array}{c}2.942 \\
(0.919)\end{array}$ & $\begin{array}{c}2.978 \\
(0.878) \\
\end{array}$ & $\begin{array}{c}0.036 \\
(0.004)\end{array}$ & $\begin{array}{c}2.880 \\
(0.887)\end{array}$ & $\begin{array}{c}-0.062 \\
(0.005) \\
\end{array}$ \\
\hline $\mathrm{N}$ & 128,736 & 83,737 & -- & 59,124 & -- \\
\hline
\end{tabular}

Notes: Each observation is a student-by-semester, so most students are included twice. Sample includes all students during the 2011-2012 academic year. The "other" race category includes students who identify as American Indian, Asian American, Hawaiian, or Multi-racial. Data on institutions come from the 2011-2012 academic year and all financial variables are expressed in nominal dollars. Means for college characteristics are enrollment-weighted. Standard deviations (errors for difference) appear in parentheses. Standard errors for differences in average institutional characteristics by pricing policy are based on a total sample size of 15 institutions. 
Table 2. Marginal Tuition Pricing and College Credits Attempted and Earned

Individual controls, excluding UM-Ann Arbor

\begin{tabular}{|c|c|c|c|c|c|c|c|c|c|c|}
\hline \multirow[b]{3}{*}{ Outcome } & \multicolumn{5}{|c|}{ Credits Attempted } & \multicolumn{5}{|c|}{ Credits Earned } \\
\hline & \multicolumn{3}{|c|}{ Full-time Students } & \multicolumn{2}{|c|}{ All Students } & \multicolumn{3}{|c|}{ Full-time Students } & \multicolumn{2}{|c|}{ All Students } \\
\hline & mean & $(1)$ & $(2)$ & mean & (3) & mean & (4) & (5) & mean & (6) \\
\hline Average credits & 14.41 & $\begin{array}{c}0.194 \\
{[0.664]}\end{array}$ & $\begin{array}{c}0.181 \\
{[0.708]}\end{array}$ & 13.85 & $\begin{array}{c}0.271 \\
{[0.616]}\end{array}$ & 13.10 & $\begin{array}{c}-0.033 \\
{[0.848]}\end{array}$ & $\begin{array}{c}-0.011 \\
{[0.964]}\end{array}$ & 12.52 & $\begin{array}{c}0.071 \\
{[0.956]}\end{array}$ \\
\hline 12 or more credits & & & & 0.91 & $\begin{array}{c}0.021 \\
{[0.508]}\end{array}$ & & & & 0.77 & $\begin{array}{c}-0.009 \\
{[0.736]}\end{array}$ \\
\hline 13 or more credits & 0.79 & $\begin{array}{c}0.072 * * \\
{[0.040]}\end{array}$ & $\begin{array}{l}0.074^{* *} \\
{[0.032]}\end{array}$ & 0.72 & $\begin{array}{c}0.082 \\
{[0.188]}\end{array}$ & 0.64 & $\begin{array}{c}0.020 \\
{[0.632]}\end{array}$ & $\begin{array}{c}0.025 \\
{[0.280]}\end{array}$ & 0.59 & $\begin{array}{c}0.032 \\
{[0.476]}\end{array}$ \\
\hline 15 or more credits & 0.46 & $\begin{array}{c}0.071 \\
{[0.348]}\end{array}$ & $\begin{array}{c}0.068 \\
{[0.388]}\end{array}$ & 0.42 & $\begin{array}{c}0.070 \\
{[0.384]}\end{array}$ & 0.36 & $\begin{array}{c}0.031 \\
{[0.488]}\end{array}$ & $\begin{array}{c}0.030 \\
{[0.528]}\end{array}$ & 0.33 & $\begin{array}{c}0.033 \\
{[0.48]}\end{array}$ \\
\hline Institution controls & & None & $\begin{array}{c}\text { ACT } \\
\text { composite }\end{array}$ & & $\begin{array}{c}\text { ACT } \\
\text { composite }\end{array}$ & & None & $\begin{array}{c}\text { ACT } \\
\text { composite }\end{array}$ & & $\begin{array}{c}\text { ACT } \\
\text { composite }\end{array}$ \\
\hline
\end{tabular}

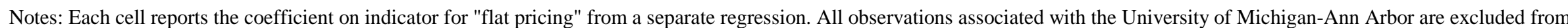

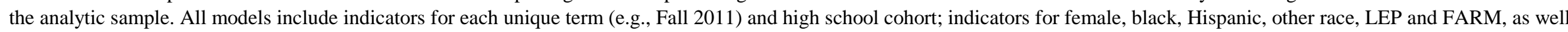
as composite ACT score. "All students" sample includes all in-state students enrolled in a Michigan public university in the 2011-2012 academic year, resulting in 187,853 student-term

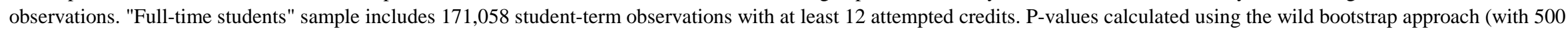
repetitions) recommended by Cameron, Gelbach, and Miller (2008) for few clusters appear in brackets: $* * * p<0.01, * * p<0.05$, $* p<0.1$. 
Table 3. Marginal Tuition Pricing and Course Performance Individual controls, institution-level ACT, excluding UM-Ann Arbor

\begin{tabular}{|c|c|c|}
\hline & $\frac{\text { All Students }}{(1)}$ & $\frac{\text { Full-time Students }}{(2)}$ \\
\hline \multicolumn{3}{|c|}{ Panel A. Outcome = Withdrew from at least one class } \\
\hline Flat pricing & $\begin{array}{l}0.058^{*} \\
{[0.084]}\end{array}$ & $\begin{array}{c}0.059 * * * \\
{[0.001]}\end{array}$ \\
\hline Outcome mean & 0.110 & 0.109 \\
\hline \multicolumn{3}{|c|}{ Panel B. Outcome = Failed at least one class } \\
\hline Flat pricing & $\begin{array}{c}0.001 \\
{[0.896]}\end{array}$ & $\begin{array}{c}0.004 \\
{[0.772]}\end{array}$ \\
\hline Outcome mean & 0.131 & 0.122 \\
\hline \multicolumn{3}{|c|}{ Panel C. Outcome $=$ Term GPA } \\
\hline Flat pricing & $\begin{array}{l}-0.050 \\
{[0.216]}\end{array}$ & $\begin{array}{c}-0.054^{* *} \\
{[0.012]}\end{array}$ \\
\hline Outcome mean & 3.052 & 3.077 \\
\hline
\end{tabular}

Notes: Each cell reports the coefficient on indicator for "flat pricing" from a separate regression. All observations associated with the University of Michigan-Ann Arbor are excluded from the analytic sample. All models include indicators for each unique term (e.g., Fall 2011) and high school cohort; indicators for female, black, Hispanic, other race, LEP and FARM, as well as composite ACT score; and institution-level ACT midpoint. "All students" sample includes all in-state students enrolled in a Michigan public university in the 2011-2012 academic year, resulting in a maximum of 187,853 student-term observations. "Full-time students" sample includes a maximum of 171,058 student-term observations with at least 12 credits attempted. P-values calculated using the wild bootstrap approach (with 500 repetitions) recommended by Cameron, Gelbach, and Miller (2008) for few clusters appear in brackets: ${ }^{* * *} \mathrm{p}<0.01,{ }^{* *} \mathrm{p}<0.05,{ }^{*} \mathrm{p}<0.1$. 
Table 4. Robustness of Main Results

Full-time students, excluding UM-Ann Arbor

\begin{tabular}{|c|c|c|c|c|c|c|c|c|c|c|}
\hline & \multirow[b]{2}{*}{ Base model } & \multirow[b]{2}{*}{$\begin{array}{l}2011 \text { Cohort } \\
\text { only }\end{array}$} & \multicolumn{3}{|c|}{ Student sorting } & \multicolumn{3}{|c|}{ Institutional characteristics } & \multicolumn{2}{|c|}{ Price structure } \\
\hline & & & Group FEs & (4) & (5) & $\begin{array}{c}\text { Instructional } \\
\text { and student } \\
\text { services } \\
\text { spending per } \\
\text { FTE } \\
\text { (6) } \\
\end{array}$ & $\begin{array}{l}\text { Admissions } \\
\text { rate }\end{array}$ & $\begin{array}{c}\text { Number of } \\
\text { full-time } \\
\text { faculty per } \\
\text { FTE } \\
(8) \\
\end{array}$ & $\begin{array}{l}\text { Marginal } \\
\text { price in } \\
\text { dollars } \\
\text { (rather than } \\
\text { indicator) } \\
\\
(9) \\
\end{array}$ & $\begin{array}{c}\text { Categorize } \\
\text { UM-D and } \\
\text { UM-F as per- } \\
\text { credit } \\
(10) \\
\end{array}$ \\
\hline \multicolumn{11}{|l|}{ 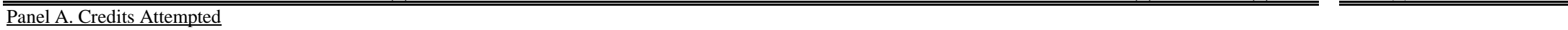 } \\
\hline Average credits attempted & $\begin{array}{c}0.181 \\
{[0.708]}\end{array}$ & $\begin{array}{c}0.240 \\
{[0.560]}\end{array}$ & $\begin{array}{c}0.171 \\
{[0.648]}\end{array}$ & $\begin{array}{c}0.149 \\
{[0.682]}\end{array}$ & $\begin{array}{c}-0.081 \\
{[0.820]}\end{array}$ & $\begin{array}{c}-0.171 \\
{[0.812]}\end{array}$ & $\begin{array}{c}0.278 \\
{[0.488]}\end{array}$ & $\begin{array}{c}0.068 \\
{[0.880]}\end{array}$ & $\begin{array}{c}-0.030 \\
{[0.884]}\end{array}$ & $\begin{array}{c}0.372 \\
{[0.432]}\end{array}$ \\
\hline 13 or more credits attempted & $\begin{array}{l}0.074^{* *} \\
{[0.032]}\end{array}$ & $\begin{array}{l}0.083^{* *} \\
{[0.016]}\end{array}$ & $\begin{array}{c}0.073^{* *} \\
{[0.044]}\end{array}$ & $\begin{array}{l}0.072 * * \\
{[0.036]}\end{array}$ & $\begin{array}{c}0.048 \\
{[0.419]}\end{array}$ & $\begin{array}{c}0.053 \\
{[0.316]}\end{array}$ & $\begin{array}{c}0.054^{*} \\
{[0.100]}\end{array}$ & $\begin{array}{c}0.070 \\
{[0.120]}\end{array}$ & $\begin{array}{c}-0.022^{*} \\
{[0.060]}\end{array}$ & $\begin{array}{c}0.104^{* * *} \\
{[0.000]}\end{array}$ \\
\hline 15 or more credits attempted & $\begin{array}{c}0.068 \\
{[0.388]}\end{array}$ & $\begin{array}{c}0.042 \\
{[0.544]}\end{array}$ & $\begin{array}{c}0.066 \\
{[0.342]}\end{array}$ & $\begin{array}{c}0.061 \\
{[0.348]}\end{array}$ & $\begin{array}{c}0.010 \\
{[0.891]}\end{array}$ & $\begin{array}{c}-0.024 \\
{[0.864]}\end{array}$ & $\begin{array}{c}0.083 \\
{[0.364]}\end{array}$ & $\begin{array}{c}0.046 \\
{[0.512]}\end{array}$ & $\begin{array}{l}-0.017 \\
{[0.584]}\end{array}$ & $\begin{array}{c}0.120 \\
{[0.104]}\end{array}$ \\
\hline \multicolumn{11}{|l|}{ Panel B. Credits Earned } \\
\hline Average credits earned & $\begin{array}{l}-0.011 \\
{[0.964]}\end{array}$ & $\begin{array}{c}0.057 \\
{[0.804]}\end{array}$ & $\begin{array}{l}-0.023 \\
{[0.898]}\end{array}$ & $\begin{array}{l}-0.028 \\
{[0.873]}\end{array}$ & $\begin{array}{l}-0.239 \\
{[0.282]}\end{array}$ & $\begin{array}{c}-0.234 \\
{[0.208]}\end{array}$ & $\begin{array}{c}0.007 \\
{[0.984]}\end{array}$ & $\begin{array}{c}-0.088 \\
{[0.636]}\end{array}$ & $\begin{array}{c}0.018 \\
{[0.820]}\end{array}$ & $\begin{array}{c}0.126 \\
{[0.628]}\end{array}$ \\
\hline 13 or more credits earned & $\begin{array}{c}0.025 \\
{[0.280]}\end{array}$ & $\begin{array}{c}0.039 \\
{[0.360]}\end{array}$ & $\begin{array}{c}0.023 \\
{[0.259]}\end{array}$ & $\begin{array}{c}0.024 \\
{[0.239]}\end{array}$ & $\begin{array}{c}0.010 \\
{[0.824]}\end{array}$ & $\begin{array}{c}0.013 \\
{[0.588]}\end{array}$ & $\begin{array}{c}0.007 \\
{[0.752]}\end{array}$ & $\begin{array}{c}0.022 \\
{[0.368]}\end{array}$ & $\begin{array}{l}-0.008 \\
{[0.300]}\end{array}$ & $\begin{array}{l}0.046^{*} \\
{[0.068]}\end{array}$ \\
\hline 15 or more credits earned & $\begin{array}{c}0.030 \\
{[0.528]}\end{array}$ & $\begin{array}{c}0.011 \\
{[0.800]}\end{array}$ & $\begin{array}{c}0.028 \\
{[0.514]}\end{array}$ & $\begin{array}{c}0.025 \\
{[0.529]}\end{array}$ & $\begin{array}{l}-0.011 \\
{[0.828]}\end{array}$ & $\begin{array}{l}-0.036 \\
{[0.496]}\end{array}$ & $\begin{array}{c}0.038 \\
{[0.524]}\end{array}$ & $\begin{array}{c}0.016 \\
{[0.700]}\end{array}$ & $\begin{array}{c}-0.007 \\
{[0.652]}\end{array}$ & $\begin{array}{c}0.068 \\
{[0.132]}\end{array}$ \\
\hline \multicolumn{11}{|l|}{ Panel C. Course Performance } \\
\hline Withdrew from at least one course & $\begin{array}{c}0.059 * * * \\
{[0.000]}\end{array}$ & $\begin{array}{c}0.048^{* * *} \\
{[0.000]}\end{array}$ & $\begin{array}{c}0.059^{* * *} \\
{[0.001]}\end{array}$ & $\begin{array}{c}0.057^{* * *} \\
{[0.000]}\end{array}$ & $\begin{array}{c}0.044 \\
{[0.113]}\end{array}$ & $\begin{array}{l}0.042 * \\
{[0.076]}\end{array}$ & $\begin{array}{l}0.058^{* *} \\
{[0.012]}\end{array}$ & $\begin{array}{c}0.059 * * * \\
{[0.000]}\end{array}$ & $\begin{array}{c}-0.018^{* * *} \\
{[0.004]}\end{array}$ & $\begin{array}{c}0.074 * * * \\
{[0.000]}\end{array}$ \\
\hline Failed at least one course & $\begin{array}{c}0.004 \\
{[0.772]}\end{array}$ & $\begin{array}{l}-0.005 \\
{[0.856]}\end{array}$ & $\begin{array}{c}0.005 \\
{[0.726]}\end{array}$ & $\begin{array}{c}0.003 \\
{[0.855]}\end{array}$ & $\begin{array}{c}0.013 \\
{[0.396]}\end{array}$ & $\begin{array}{c}-0.003 \\
{[0.900]}\end{array}$ & $\begin{array}{c}0.003 \\
{[0.768]}\end{array}$ & $\begin{array}{c}0.005 \\
{[0.760]}\end{array}$ & $\begin{array}{l}-0.001 \\
{[0.812]}\end{array}$ & $\begin{array}{c}0.003 \\
{[0.792]}\end{array}$ \\
\hline Term GPA & $\begin{array}{c}-0.054^{* *} \\
{[0.012]}\end{array}$ & $\begin{array}{c}-0.045 \\
{[0.204]}\end{array}$ & $\begin{array}{c}-0.055^{* * *} \\
{[0.008]}\end{array}$ & $\begin{array}{c}-0.050^{* * *} \\
{[0.009]}\end{array}$ & $\begin{array}{c}-0.073^{* *} \\
{[0.028]}\end{array}$ & $\begin{array}{c}-0.023 \\
{[0.172]}\end{array}$ & $\begin{array}{c}-0.050^{* *} \\
{[0.016]}\end{array}$ & $\begin{array}{c}-0.051^{* *} \\
{[0.016]}\end{array}$ & $\begin{array}{c}0.016^{* *} \\
{[0.020]}\end{array}$ & $\begin{array}{c}-0.055^{* *} \\
{[0.012]}\end{array}$ \\
\hline Student controls? & Linear & Linear & $\begin{array}{l}\text { Group fixed } \\
\text { effects }\end{array}$ & $\begin{array}{l}\text { Linear plus } \\
\text { HS fixed } \\
\text { effects }\end{array}$ & Linear & Linear & Linear & Linear & Linear & Linear \\
\hline Institution controls? & $\begin{array}{c}\text { ACT } \\
\text { composite }\end{array}$ & $\begin{array}{c}\text { ACT } \\
\text { composite }\end{array}$ & $\begin{array}{c}\text { ACT } \\
\text { composite }\end{array}$ & $\begin{array}{c}\text { ACT } \\
\text { composite }\end{array}$ & $\begin{array}{c}\text { ACT } \\
\text { composite }\end{array}$ & $\begin{array}{c}\text { ACT } \\
\text { composite } \\
\text { plus spending } \\
\text { controls }\end{array}$ & $\begin{array}{c}\text { ACT } \\
\text { composite } \\
\text { plus } \\
\text { selectivity } \\
\text { control }\end{array}$ & $\begin{array}{c}\text { ACT } \\
\text { composite } \\
\text { plus faculty } \\
\text { resource } \\
\text { control }\end{array}$ & $\begin{array}{c}\text { ACT } \\
\text { composite }\end{array}$ & $\begin{array}{c}\text { ACT } \\
\text { composite }\end{array}$ \\
\hline
\end{tabular}

Notes: Each cell reports the coefficient on indicator for "flat pricing" from a separate regression. Column (9) is the exception: it reports the coefficient on a continuous measure of marginal price denominated in 100-dollar increments (20112012 dollars). All observations associated with the University of Michigan-Ann Arbor are excluded from the analytic sample. All models include indicators for each unique term (e.g., Fall 2011) and high school cohort; indicators for female, black, Hispanic, other race, LEP and FARM, as well as composite ACT score. Sample sizes for columns (2) and (3) are 46,414 and 80,310 respectively. All other specifications have a maximum sample size of 171,058. Except for columns (3), (4), and (5), in which p-values are based on standard errors clustered by college, p-values calculated using the wild bootstrap approach (with 500 repetitions) recommended by Cameron, Gelbach, and Miller (2008) for few clusters appear in

brackets: *** $\mathrm{p}<0.01, * * \mathrm{p}<0.05, * \mathrm{p}<0.1$. 
Table 5. Marginal Tuition Pricing and College Persistence, First-time Fall Enrollees at MI Public Universities Individual controls, institution-level ACT, excluding UM-Ann Arbor

\begin{tabular}{|c|c|c|c|c|}
\hline & \multicolumn{2}{|c|}{ Outcome = Enrolled in Any College } & \multicolumn{2}{|c|}{$\begin{array}{c}\text { Outcome = Enrolled in MI Public } \\
\text { 4-Year College }\end{array}$} \\
\hline & mean & $(1)$ & mean & $(2)$ \\
\hline $\begin{array}{l}\text { Enrolled 1st Spring } \\
(\max n=103,362)\end{array}$ & 0.960 & $\begin{array}{l}-0.005 \\
{[0.712]}\end{array}$ & 0.931 & $\begin{array}{l}-0.006 \\
{[0.676]}\end{array}$ \\
\hline $\begin{array}{l}\text { Enrolled 2nd Fall } \\
(\max n=77,543)\end{array}$ & 0.914 & $\begin{array}{c}-0.012 \\
{[0.488]}\end{array}$ & 0.819 & $\begin{array}{c}-0.023 \\
{[0.280]}\end{array}$ \\
\hline Enrolled 2nd Spring & 0.885 & $\begin{array}{c}-0.011 \\
{[0.592]}\end{array}$ & 0.774 & $\begin{array}{c}-0.009 \\
{[0.724]}\end{array}$ \\
\hline $\begin{array}{l}\text { Enrolled 3rd Fall } \\
(\max n=51,653)\end{array}$ & 0.855 & $\begin{array}{l}-0.015 \\
{[0.468]}\end{array}$ & 0.735 & $\begin{array}{c}-0.015 \\
{[0.504]}\end{array}$ \\
\hline Enrolled 3rd Spring & 0.833 & $\begin{array}{l}-0.017 \\
{[0.460]}\end{array}$ & 0.711 & $\begin{array}{l}-0.010 \\
{[0.688]}\end{array}$ \\
\hline $\begin{array}{l}\text { Enrolled 4th Fall } \\
(\max n=26,205)\end{array}$ & 0.810 & $\begin{array}{l}-0.020 \\
{[0.400]}\end{array}$ & 0.695 & $\begin{array}{l}-0.015 \\
{[0.532]}\end{array}$ \\
\hline Enrolled 4th Spring & 0.764 & $\begin{array}{c}-0.057 \\
{[0.252]}\end{array}$ & 0.652 & $\begin{array}{c}-0.050 \\
{[0.312]}\end{array}$ \\
\hline
\end{tabular}

Notes: Each cell reports the coefficient on indicator for "flat pricing" at first institution attended from a separate regression. Sample is restricted to MI public high school graduates from 2008 to 2011 that enrolled in a MI public university in the fall immediately after high school graduation, excluding University of Michigan-Ann Arbor. All models include cohort fixed effects and ACT composite score of first institution attended. Individual controls include dummies for female, black, Hispanic, other race, LEP, and FARM, and composite ACT score. P-values calculated using the wild bootstrap approach (with 500 repetitions) recommended by Cameron, Gelbach, and Miller (2008) for few clusters appear in brackets: $* * * \mathrm{p}<0.01, * *$ $\mathrm{p}<0.05,{ }^{*} \mathrm{p}<0.1$. 
Table 6. Marginal Tuition Pricing and Cumulative College Credits Attempted and Earned as of Winter 2012 Individual controls, institution-level ACT, excluding UM-Ann Arbor

\begin{tabular}{|c|c|c|c|}
\hline & $\begin{array}{l}\text { Cumulative } \\
\text { credits } \\
\text { attempted } \\
\text { (1) }\end{array}$ & $\begin{array}{c}\text { Cumulative } \\
\text { credits earned } \\
\text { (2) }\end{array}$ & $\begin{array}{c}\text { "On-time" } \\
\text { cumulative } \\
\text { credits earned } \\
\text { (3) }\end{array}$ \\
\hline \multicolumn{4}{|c|}{ Panel A. High school class of 2010} \\
\hline \multicolumn{4}{|c|}{ "On-time" = 60 credits earned by Winter 2012, n = 17,447 students } \\
\hline Flat pricing & $\begin{array}{c}0.625 \\
{[0.788]}\end{array}$ & $\begin{array}{c}0.279 \\
{[0.876]}\end{array}$ & $\begin{array}{c}-0.001 \\
{[0.928]}\end{array}$ \\
\hline Outcome mean & 59.01 & 54.45 & 0.30 \\
\hline \multicolumn{4}{|c|}{ Panel B. High school class of 2009} \\
\hline \multicolumn{4}{|c|}{ "On-time" = 90 credits earned by Winter 2012, n = 13,574 students } \\
\hline Flat pricing & $\begin{array}{c}0.995 \\
{[0.780]}\end{array}$ & $\begin{array}{c}0.327 \\
{[0.864]}\end{array}$ & $\begin{array}{c}-0.028 \\
{[0.572]}\end{array}$ \\
\hline Outcome mean & 89.63 & 83.46 & 0.35 \\
\hline \multicolumn{4}{|c|}{ Panel C. High school class of 2008} \\
\hline \multicolumn{4}{|c|}{ "On-time" = 120 credits earned by Winter 2012, n = 9,913 students } \\
\hline Flat pricing & $\begin{array}{c}2.306 \\
{[0.628]}\end{array}$ & $\begin{array}{c}1.011 \\
{[0.720]}\end{array}$ & $\begin{array}{c}0.007 \\
{[0.940]}\end{array}$ \\
\hline Outcome mean & 119.82 & 111.79 & 0.36 \\
\hline
\end{tabular}

Notes: Each cell reports the coefficient on indicator for "flat pricing" from a separate regression. Sample is restricted to students enrolled (part-time or full-time) in all fall and winter semesters since high school graduation and for which NSC and STARR data agree on enrollment history. Cumulative credits include credits taken during summer terms. All models include dummies for female, black, Hispanic, other race, LEP and FARM and composite ACT score of individual, midpoint ACT of the institution, and exclude University of Michigan-Ann Arbor. P-values calculated using the wild bootstrap approach (with 500 repetitions) recommended by Cameron, Gelbach, and Miller (2008) for few clusters appear in brackets: ${ }^{* * *} \mathrm{p}<0.01,{ }^{* *} \mathrm{p}<0.05,{ }^{*} \mathrm{p}<0.1$. 


\section{Appendix A. Additional Tables (Referenced in Main Text)}

Table A1. Marginal Pricing Practices at Michigan’s 4-year Public Universities

Table A2. Cohort-specific Estimates

Table A3. First-Stage Estimates for 2SLS Approach

Table A4. Correlations between Institutional Characteristics

Table A5. Effects by Quintile of Predicted Credits Attempted

Table A6. Effects by Student Gender and Poverty Status

Table A7. Robustness of Cumulative Credits and Persistence 
Table A1. Marginal Pricing Practices at Michigan's 4-year Public Universities

\begin{tabular}{|c|c|c|c|c|c|c|}
\hline & \multirow[b]{2}{*}{ Type } & \multirow[b]{2}{*}{$\begin{array}{c}\text { Per-credit price } \\
(2011 / 2012)\end{array}$} & \multirow[b]{2}{*}{ Flat range } & \multicolumn{2}{|c|}{ Price differentials by... } & \multirow{2}{*}{$\begin{array}{l}\text { Withdrawal Policy } \\
\text { Can receive full (or near full) refund } \\
\text { of tuition and fees if withdraw by... }\end{array}$} \\
\hline & & & & $\begin{array}{c}\text { Level } \\
\text { (upper vs. lower) }\end{array}$ & $\begin{array}{c}\text { Program or } \\
\text { school }\end{array}$ & \\
\hline Central Michigan University & per credit & $\$ 358$ & & & & second meeting of course \\
\hline Eastern Michigan University & per credit & $\$ 247$ & & & & one week into course \\
\hline Ferris State University & per credit & $\$ 348$ & & & & fourth day of the semester \\
\hline Grand Valley State University & flat & & $12-16$ credits & yes & & end of first week of classes \\
\hline Lake Superior State University & flat & & $12-17$ credits & & & sixth day of the semester \\
\hline Michigan State University & per credit & $\$ 407$ & & yes & yes & one-fourth of term of the class* \\
\hline Michigan Technological University & per credit & $\$ 421$ & & & & second Wednesday of semester \\
\hline Northern Michigan University & flat & & 12-18 credit & & & one week into course \\
\hline Oakland University & per credit & $\$ 331$ & & yes & & two weeks into course \\
\hline Saginaw Valley State University & per credit & $\$ 246$ & & & & end of first week of classes \\
\hline University of Michigan-Ann Arbor & flat & & $12-18$ credits & yes & yes & three weeks into course \\
\hline University of Michigan-Dearborn & flat & & $>12$ & & & two weeks into course \\
\hline University of Michigan-Flint & flat & & $>12$ & & & three weeks into course \\
\hline Wayne State University & per credit & $\$ 287$ & & yes & yes & two weeks into course \\
\hline Western Michigan University & flat & & $12-15$ credits & yes & & one week into course \\
\hline
\end{tabular}

Source: Presidents Council, State Universities of Michigan, Report on Tuition and Fees 2011-2012

Notes: UM-Dearborn and UM-Flint charge $\$ 80$ for each credit above 12, though this is substantially lower than the rate charged per credit up to 12 . Withdrawal and refund policies come directly from each institution's registrar, business, and/or records websites. $*=$ measured in weekdays not class days. 
TableA2. Cohort-specific Estimates

Full-time students, individual controls, institution-level ACT, excluding UM-Ann Arbor

\begin{tabular}{|c|c|c|c|c|c|}
\hline & \multirow[b]{2}{*}{ All cohorts } & \multicolumn{4}{|c|}{ Separately by Cohort } \\
\hline & & $\begin{array}{l}2011 \text { Cohort } \\
\text { only }\end{array}$ & $\begin{array}{l}2010 \text { Cohort } \\
\text { only }\end{array}$ & $\begin{array}{l}2009 \text { Cohort } \\
\text { only }\end{array}$ & $\begin{array}{c}2008 \text { Cohort } \\
\text { only }\end{array}$ \\
\hline & $(1)$ & $(2)$ & (3) & (4) & $(5)$ \\
\hline \multicolumn{6}{|l|}{ 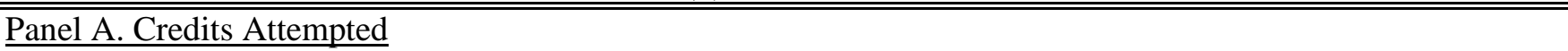 } \\
\hline Average credits attempted & $\begin{array}{c}0.181 \\
{[0.708]}\end{array}$ & $\begin{array}{c}0.240 \\
{[0.560]}\end{array}$ & $\begin{array}{c}0.043 \\
{[0.948]}\end{array}$ & $\begin{array}{c}0.215 \\
{[0.724]}\end{array}$ & $\begin{array}{c}0.225 \\
{[0.696]}\end{array}$ \\
\hline 13 or more credits attempted & $\begin{array}{c}0.074 * * \\
{[0.032]}\end{array}$ & $\begin{array}{c}0.083 * * \\
{[0.016]}\end{array}$ & $\begin{array}{c}0.067 * \\
{[0.056]}\end{array}$ & $\begin{array}{c}0.078 * * \\
{[0.024]}\end{array}$ & $\begin{array}{c}0.068 \\
{[0.144]}\end{array}$ \\
\hline 15 or more credits attempted & $\begin{array}{c}0.068 \\
{[0.388]}\end{array}$ & $\begin{array}{c}0.042 \\
{[0.544]}\end{array}$ & $\begin{array}{c}0.050 \\
{[0.572]}\end{array}$ & $\begin{array}{c}0.097 \\
{[0.228]}\end{array}$ & $\begin{array}{c}0.086 \\
{[0.312]}\end{array}$ \\
\hline \multicolumn{6}{|l|}{ Panel B. Credits Earned } \\
\hline Average credits earned & $\begin{array}{c}-0.011 \\
{[0.964]}\end{array}$ & $\begin{array}{c}0.057 \\
{[0.804]}\end{array}$ & $\begin{array}{c}-0.134 \\
{[0.572]}\end{array}$ & $\begin{array}{c}0.006 \\
{[0.984]}\end{array}$ & $\begin{array}{c}0.027 \\
{[0.936]}\end{array}$ \\
\hline 13 or more credits earned & $\begin{array}{c}0.025 \\
{[0.280]}\end{array}$ & $\begin{array}{c}0.039 \\
{[0.360]}\end{array}$ & $\begin{array}{c}0.014 \\
{[0.728]}\end{array}$ & $\begin{array}{c}0.025 \\
{[0.252]}\end{array}$ & $\begin{array}{c}0.022 \\
{[0.456]}\end{array}$ \\
\hline 15 or more credits earned & $\begin{array}{c}0.030 \\
{[0.528]}\end{array}$ & $\begin{array}{c}0.011 \\
{[0.800]}\end{array}$ & $\begin{array}{c}0.012 \\
{[0.844]}\end{array}$ & $\begin{array}{c}0.049 \\
{[0.364]}\end{array}$ & $\begin{array}{c}0.051 \\
{[0.336]}\end{array}$ \\
\hline \multicolumn{6}{|l|}{ Panel C. Course Performance } \\
\hline Withdrew from at least one course & $\begin{array}{c}0.059 * * * \\
{[0.000]}\end{array}$ & $\begin{array}{c}0.048 * * * \\
{[0.000]}\end{array}$ & $\begin{array}{c}0.062 * * * \\
{[0.000]}\end{array}$ & $\begin{array}{c}0.062 * * * \\
{[0.000]}\end{array}$ & $\begin{array}{c}0.064^{* * *} \\
{[0.000]}\end{array}$ \\
\hline Failed at least one course & $\begin{array}{c}0.004 \\
{[0.772]}\end{array}$ & $\begin{array}{c}-0.005 \\
{[0.856]}\end{array}$ & $\begin{array}{c}0.002 \\
{[0.884]}\end{array}$ & $\begin{array}{c}0.007 \\
{[0.488]}\end{array}$ & $\begin{array}{c}0.011^{*} \\
{[0.068]}\end{array}$ \\
\hline Term GPA & $\begin{array}{c}-0.054^{* *} \\
{[0.012]}\end{array}$ & $\begin{array}{l}-0.045 \\
{[0.204]}\end{array}$ & $\begin{array}{c}-0.066^{* *} \\
{[0.036]}\end{array}$ & $\begin{array}{c}-0.056^{* *} \\
{[0.036]}\end{array}$ & $\begin{array}{l}-0.049 \\
{[0.120]}\end{array}$ \\
\hline Sample size & 171,058 & 46,414 & 41,855 & 42,253 & 40,536 \\
\hline Student controls? & Linear & Linear & Linear & Linear & Linear \\
\hline Institution controls? & $\begin{array}{c}\text { ACT } \\
\text { composite }\end{array}$ & $\begin{array}{c}\text { ACT } \\
\text { composite }\end{array}$ & $\begin{array}{c}\text { ACT } \\
\text { composite }\end{array}$ & $\begin{array}{c}\text { ACT } \\
\text { composite }\end{array}$ & $\begin{array}{c}\text { ACT } \\
\text { composite }\end{array}$ \\
\hline
\end{tabular}

Notes: Each cell reports the coefficient on indicator for "flat pricing" from a separate regression. All observations associated with the University of Michigan-Ann Arbor are excluded from the analytic sample. All models include indicators for each unique term (e.g., Fall 2011) and high school cohort; indicators for female, black, Hispanic, other race, LEP and FARM, as well as composite ACT score. P-values calculated using the wild bootstrap approach (with 500 repetitions) recommended by Cameron, Gelbach, and Miller (2008) for few clusters appear in brackets: *** $\mathrm{p}<0.01, * * \mathrm{p}<0.05,{ }^{*} \mathrm{p}<0.1$. 
Table A3. First-Stage Results for 2SLS Approach

\begin{tabular}{lc}
\hline & $\begin{array}{c}\text { Outcome }=\text { Current } \\
\text { institution has flat } \\
\text { pricing } \\
(1)\end{array}$ \\
\hline Flat pricing (closest institution) & 0.210 \\
& $(0.057)^{* * *}$ \\
Student-level covariates & Yes \\
High school cohort indicators & Yes \\
Semester indicators & Yes \\
\hline R-squared & \\
$\mathrm{N}$ & 0.059 \\
\hline
\end{tabular}

Notes: 2SLS = two-stage least squares; Sample is limited to full-time students. This first-stage underpins estimates from Table 4, column 5 in main text. Robust standard errors clustered by college appear in parentheses: ${ }^{* * *} \mathrm{p}<0.01,{ }^{* *} \mathrm{p}<0.05,{ }^{*} \mathrm{p}<0.1$. 
Table A4. Correlations between Institutional Characteristics

\begin{tabular}{|c|c|c|c|c|c|}
\hline & $\begin{array}{c}\text { ACT } \\
\text { midpoint }\end{array}$ & $\begin{array}{l}\text { FT faculty } \\
\text { per FTE }\end{array}$ & $\begin{array}{c}\text { Instructional } \\
\text { spending per } \\
\text { FTE }\end{array}$ & $\begin{array}{c}\text { Student } \\
\text { services } \\
\text { spending per } \\
\text { FTE } \\
\end{array}$ & $\begin{array}{c}\text { Admissions } \\
\text { rate }\end{array}$ \\
\hline \multicolumn{6}{|l|}{ A. All 15 institutions (unweighted) } \\
\hline ACT midpoint & 1.00 & & & & \\
\hline FT faculty per FTE & 0.84 & 1.00 & & & \\
\hline Instructional spending per FTE & 0.82 & 0.93 & 1.00 & & \\
\hline Student services spending per FTE & 0.31 & 0.54 & 0.37 & 1.00 & \\
\hline Admissions rate & -0.63 & -0.64 & -0.70 & -0.44 & 1.00 \\
\hline FT student retention rate & 0.88 & 0.77 & 0.85 & 0.26 & -0.65 \\
\hline \multicolumn{6}{|l|}{ B. Excluding UM-AA (unweighted) } \\
\hline ACT midpoint & 1.00 & & & & \\
\hline FT faculty per FTE & 0.53 & 1.00 & & & \\
\hline Instructional spending per FTE & 0.49 & 0.78 & 1.00 & & \\
\hline Student services spending per FTE & -0.04 & 0.40 & 0.07 & 1.00 & \\
\hline Admissions rate & -0.15 & -0.06 & -0.30 & -0.23 & 1.00 \\
\hline FT student retention rate & 0.78 & 0.54 & 0.72 & -0.01 & -0.34 \\
\hline \multicolumn{6}{|c|}{ C. Excluding UM-AA (weighted by enrollment) } \\
\hline ACT midpoint & 1.00 & & & & \\
\hline FT faculty per FTE & 0.33 & 1.00 & & & \\
\hline Instructional spending per FTE & 0.55 & 0.78 & 1.00 & & \\
\hline Student services spending per FTE & -0.49 & 0.20 & -0.18 & 1.00 & \\
\hline Admissions rate & -0.02 & 0.05 & -0.18 & -0.12 & 1.00 \\
\hline FT student retention rate & 0.87 & 0.47 & 0.75 & -0.37 & -0.14 \\
\hline
\end{tabular}

Notes: Table reports pair-wise correlation coefficients between institution-level characteristics. Includes 14 4-year public institutions in Michigan (15 in panel A). 
Table A5. Effects by Quintile of Predicted Credits Attempted

Full-time students, individual controls, institution-level ACT, excluding UM-Ann Arbor

\begin{tabular}{|c|c|c|c|c|c|}
\hline & \multicolumn{5}{|c|}{ Quintile of Predicted Credits Attempted } \\
\hline & 1 (low) & 2 & 3 & 4 & 5 (high) \\
\hline & $(1)$ & $(2)$ & $(3)$ & $(4)$ & $(5)$ \\
\hline \multicolumn{6}{|l|}{ Panel A. Credits Attempted } \\
\hline \multirow[t]{2}{*}{ Average credits attempted } & 0.383 & 0.084 & 0.076 & 0.060 & 0.122 \\
\hline & [0.312] & {$[0.936]$} & {$[0.960]$} & [0.984] & {$[0.824]$} \\
\hline \multirow[t]{2}{*}{13 or more credits attempted } & $0.122 * *$ & 0.062 & 0.055 & 0.056 & $0.052 * *$ \\
\hline & [0.044] & {$[0.148]$} & {$[0.168]$} & {$[0.128]$} & {$[0.020]$} \\
\hline \multirow[t]{2}{*}{15 or more credits attempted } & 0.106 & 0.043 & 0.041 & 0.057 & 0.057 \\
\hline & [0.188] & {$[0.700]$} & [0.644] & [0.508] & [0.348] \\
\hline \multicolumn{6}{|l|}{ Panel B. Credits Earned } \\
\hline \multirow[t]{2}{*}{$\overline{\text { Average credits earned }}$} & 0.036 & -0.189 & -0.115 & -0.024 & 0.069 \\
\hline & [0.832] & {$[0.452]$} & {$[0.572]$} & [0.884] & {$[0.836]$} \\
\hline \multirow[t]{2}{*}{13 or more credits earned } & 0.038 & 0.011 & 0.010 & 0.026 & $0.027 * *$ \\
\hline & {$[0.100]$} & {$[0.704]$} & {$[0.700]$} & {$[0.280]$} & {$[0.044]$} \\
\hline \multirow[t]{2}{*}{15 or more credits earned } & 0.041 & 0.010 & 0.012 & 0.032 & 0.037 \\
\hline & {$[0.340]$} & {$[0.900]$} & {$[0.860]$} & {$[0.556]$} & {$[0.320]$} \\
\hline \multicolumn{6}{|l|}{ Panel C. Withdrawal or Fail } \\
\hline \multirow[t]{2}{*}{ Withdrew from at least one course } & $0.072 * * *$ & $0.065^{* * *}$ & $0.058 * * *$ & $0.056 * * *$ & $0.054 * * *$ \\
\hline & {$[0.000]$} & {$[0.000]$} & {$[0.000]$} & {$[0.000]$} & {$[0.000]$} \\
\hline \multirow[t]{2}{*}{ Failed at least one course } & 0.007 & 0.012 & 0.010 & 0.002 & -0.019 \\
\hline & [0.664] & {$[0.544]$} & {$[0.528]$} & [0.848] & {$[0.500]$} \\
\hline \multirow[t]{2}{*}{ Term GPA } & -0.028 & $-0.078 * *$ & $-0.086 * * *$ & $-0.064^{* *}$ & -0.013 \\
\hline & [0.244] & [0.032] & [0.004] & [0.024] & [0.664] \\
\hline
\end{tabular}

Notes: Each cell reports the coefficient on indicator for "flat pricing" from a separate regression. Students are grouped into quintiles based on their predicted number of credits attempted from a regression model applied to students at per-credit schools. All models include dummies for unique cohort and term, dummies for female, black, Hispanic, other race, LEP and FARM and composite ACT score of individual, midpoint ACT of the institution, and exclude UM-Ann Arbor. P-values calculated using the wild bootstrap approach (with 500 repetitions) recommended by Cameron, Gelbach, and Miller (2008) for few clusters appear in brackets: $* * * p<0.01, * * p<0.05,{ }^{*} p<0.1$. 
Table A6. Effects by Student Gender and Poverty Status

Full-time students, individual controls, institution-level ACT, excluding UM-Ann Arbor

\begin{tabular}{|c|c|c|c|c|}
\hline & $\begin{array}{c}\text { Female } \\
(1) \\
\end{array}$ & $\begin{array}{c}\text { Male } \\
(2) \\
\end{array}$ & $\begin{array}{c}\text { Non-FARM } \\
\text { (3) } \\
\end{array}$ & $\begin{array}{c}\text { FARM } \\
(4) \\
\end{array}$ \\
\hline \multicolumn{5}{|l|}{$\underline{\underline{\text { Panel A. Credits Attempted }}}$} \\
\hline Average credits attempted & $\begin{array}{c}0.183 \\
{[0.812]}\end{array}$ & $\begin{array}{c}0.182 \\
{[0.680]}\end{array}$ & $\begin{array}{c}0.160 \\
{[0.800]}\end{array}$ & $\begin{array}{c}0.404 \\
{[0.256]}\end{array}$ \\
\hline 13 or more credits attempted & $\begin{array}{l}0.079 * \\
{[0.064]}\end{array}$ & $\begin{array}{l}0.069 * \\
{[0.084]}\end{array}$ & $\begin{array}{c}0.070 * \\
{[0.068]}\end{array}$ & $\begin{array}{c}0.127 * * \\
{[0.016]}\end{array}$ \\
\hline 15 or more credits attempted & $\begin{array}{c}0.077 \\
{[0.416]}\end{array}$ & $\begin{array}{c}0.057 \\
{[0.460]}\end{array}$ & $\begin{array}{c}0.064 \\
{[0.468]}\end{array}$ & $\begin{array}{c}0.109 \\
{[0.132]}\end{array}$ \\
\hline \multicolumn{5}{|l|}{$\underline{\text { Panel B. Credits Earned }}$} \\
\hline Average credits earned & $\begin{array}{c}0.101 \\
{[0.768]}\end{array}$ & $\begin{array}{c}-0.142 \\
{[0.424]}\end{array}$ & $\begin{array}{c}-0.023 \\
{[0.864]}\end{array}$ & $\begin{array}{c}0.083 \\
{[0.624]}\end{array}$ \\
\hline 13 or more credits earned & $\begin{array}{l}0.040 * \\
{[0.084]}\end{array}$ & $\begin{array}{c}0.007 \\
{[0.816]}\end{array}$ & $\begin{array}{c}0.023 \\
{[0.340]}\end{array}$ & $\begin{array}{c}0.048 * * \\
{[0.016]}\end{array}$ \\
\hline 15 or more credits earned & $\begin{array}{c}0.042 \\
{[0.456]}\end{array}$ & $\begin{array}{c}0.016 \\
{[0.748]}\end{array}$ & $\begin{array}{c}0.028 \\
{[0.580]}\end{array}$ & $\begin{array}{c}0.044 \\
{[0.296]}\end{array}$ \\
\hline \multicolumn{5}{|l|}{ Panel C. Withdrawal or Fail } \\
\hline Withdrew from at least one course & $\begin{array}{c}0.054^{* * *} \\
{[0.000]}\end{array}$ & $\begin{array}{c}0.065^{* * *} \\
{[0.000]}\end{array}$ & $\begin{array}{c}0.058^{* * *} \\
{[0.000]}\end{array}$ & $\begin{array}{c}0.070 * * * \\
{[0.000]}\end{array}$ \\
\hline Failed at least one course & $\begin{array}{c}-0.004 \\
{[0.644]}\end{array}$ & $\begin{array}{c}0.013 \\
{[0.552]}\end{array}$ & $\begin{array}{c}0.003 \\
{[0.828]}\end{array}$ & $\begin{array}{c}0.007 \\
{[0.620]}\end{array}$ \\
\hline Term GPA & $\begin{array}{c}-0.033 \\
{[0.304]}\end{array}$ & $\begin{array}{c}-0.077^{* *} \\
{[0.012]}\end{array}$ & $\begin{array}{c}-0.053^{* *} \\
{[0.020]}\end{array}$ & $\begin{array}{c}-0.057 * * \\
{[0.048]}\end{array}$ \\
\hline $\begin{array}{l}\text { Notes: Each cell reports the coefficient on } \\
\text { dummies for unique cohort and term, dumr } \\
\text { ACT score of individual, midpoint ACT of } \\
\text { wild bootstrap approach (with } 500 \text { repetiti } \\
\text { appear in brackets: }{ }^{* * *} \mathrm{p}<0.01,{ }^{* *} \mathrm{p}<0.05\end{array}$ & $\begin{array}{l}\text { or for "flat } \\
\text { r female, bl } \\
\text { stitution, an } \\
\text { commended }\end{array}$ & $\begin{array}{l}\text { "" from a s } \\
\text { ispanic, ot } \\
\text { ude UM-A }\end{array}$ & $\begin{array}{l}\text { gression. All n } \\
\text { LEP and FARI } \\
\text { P-values calch }\end{array}$ & $\begin{array}{l}\text { els include } \\
\text { ad composite } \\
\text { d using the }\end{array}$ \\
\hline
\end{tabular}




\begin{tabular}{|c|c|c|c|c|c|c|}
\hline & \multirow[b]{2}{*}{ Base model } & \multicolumn{2}{|c|}{ Student sorting } & \multicolumn{3}{|c|}{ Institutional characteristics } \\
\hline & & Group FEs & HS FEs & $\begin{array}{l}\text { Instructional } \\
\text { and student } \\
\text { services } \\
\text { spending per } \\
\text { FTE }\end{array}$ & $\begin{array}{l}\text { Admissions } \\
\text { rate }\end{array}$ & $\begin{array}{l}\text { Number of } \\
\text { full-time } \\
\text { faculty per } \\
\text { FTE }\end{array}$ \\
\hline & $(1)$ & $(2)$ & (3) & (4) & (5) & $(6)$ \\
\hline \multicolumn{7}{|c|}{ Panel A. High school class of 2010} \\
\hline Cumulative credits attempted & $\begin{array}{c}0.625 \\
{[0.788]}\end{array}$ & $\begin{array}{c}0.492 \\
{[0.772]}\end{array}$ & $\begin{array}{c}0.395 \\
{[0.790]}\end{array}$ & $\begin{array}{c}-0.747 \\
{[0.776]}\end{array}$ & $\begin{array}{c}0.642 \\
{[0.788]}\end{array}$ & $\begin{array}{c}0.014 \\
{[0.952]}\end{array}$ \\
\hline Cumulative credits earned & $\begin{array}{c}0.279 \\
{[0.876]}\end{array}$ & $\begin{array}{c}0.150 \\
{[0.872]}\end{array}$ & $\begin{array}{c}0.056 \\
{[0.932]}\end{array}$ & $\begin{array}{c}-1.030 \\
{[0.468]}\end{array}$ & $\begin{array}{c}0.135 \\
{[0.964]}\end{array}$ & $\begin{array}{c}-0.155 \\
{[0.784]}\end{array}$ \\
\hline \multicolumn{7}{|c|}{ Panel B. High school class of 2009} \\
\hline Cumulative credits attempted & $\begin{array}{c}0.995 \\
{[0.780]}\end{array}$ & $\begin{array}{c}0.805 \\
{[0.737]}\end{array}$ & $\begin{array}{c}0.642 \\
{[0.743]}\end{array}$ & $\begin{array}{c}-0.483 \\
{[0.868]}\end{array}$ & $\begin{array}{c}0.753 \\
{[0.772]}\end{array}$ & $\begin{array}{c}0.016 \\
{[0.960]}\end{array}$ \\
\hline Cumulative credits earned & $\begin{array}{c}0.327 \\
{[0.864]}\end{array}$ & $\begin{array}{c}0.137 \\
{[0.916]}\end{array}$ & $\begin{array}{c}0.072 \\
{[0.934]}\end{array}$ & $\begin{array}{c}-1.471 \\
{[0.476]}\end{array}$ & $\begin{array}{c}-0.087 \\
{[0.924]}\end{array}$ & $\begin{array}{c}-0.553 \\
{[0.544]}\end{array}$ \\
\hline \multicolumn{7}{|c|}{ Panel C. High school class of 2008} \\
\hline Cumulative credits attempted & $\begin{array}{c}2.306 \\
{[0.628]}\end{array}$ & $\begin{array}{c}2.172 \\
{[0.537]}\end{array}$ & $\begin{array}{c}2.012 \\
{[0.523]}\end{array}$ & $\begin{array}{c}1.220 \\
{[0.856]}\end{array}$ & $\begin{array}{c}1.379 \\
{[0.680]}\end{array}$ & $\begin{array}{c}1.260 \\
{[0.764]}\end{array}$ \\
\hline Cumulative credits earned & $\begin{array}{c}1.011 \\
{[0.720]}\end{array}$ & $\begin{array}{c}0.851 \\
{[0.708]}\end{array}$ & $\begin{array}{c}0.828 \\
{[0.645]}\end{array}$ & $\begin{array}{c}-0.220 \\
{[0.956]}\end{array}$ & $\begin{array}{c}-0.053 \\
{[0.968]}\end{array}$ & $\begin{array}{c}0.138 \\
{[0.972]}\end{array}$ \\
\hline \multicolumn{7}{|c|}{ Panel D. Persistence at any college (all cohorts) } \\
\hline Enrolled 1st Spring & $\begin{array}{c}-0.005 \\
{[0.712]}\end{array}$ & $\begin{array}{c}-0.005 \\
{[0.631]}\end{array}$ & $\begin{array}{c}-0.000 \\
{[0.992]}\end{array}$ & $\begin{array}{c}-0.003 \\
{[0.708]}\end{array}$ & $\begin{array}{c}-0.010 \\
{[0.528]}\end{array}$ & $\begin{array}{c}-0.006 \\
{[0.656]}\end{array}$ \\
\hline Enrolled 2nd Fall & $\begin{array}{c}-0.012 \\
{[0.488]}\end{array}$ & $\begin{array}{c}-0.013 \\
{[0.410]}\end{array}$ & $\begin{array}{c}-0.002 \\
{[0.850]}\end{array}$ & $\begin{array}{c}-0.003 \\
{[0.824]}\end{array}$ & $\begin{array}{c}-0.010 \\
{[0.640]}\end{array}$ & $\begin{array}{c}-0.015 \\
{[0.432]}\end{array}$ \\
\hline Enrolled 2nd Spring & $\begin{array}{c}-0.011 \\
{[0.592]}\end{array}$ & $\begin{array}{c}-0.012 \\
{[0.514]}\end{array}$ & $\begin{array}{c}0.001 \\
{[0.940]}\end{array}$ & $\begin{array}{c}-0.007 \\
{[0.628]}\end{array}$ & $\begin{array}{c}-0.011 \\
{[0.596]}\end{array}$ & $\begin{array}{c}-0.014 \\
{[0.512]}\end{array}$ \\
\hline Enrolled 3rd Fall & $\begin{array}{c}-0.015 \\
{[0.468]}\end{array}$ & $\begin{array}{c}-0.017 \\
{[0.389]}\end{array}$ & $\begin{array}{c}-0.002 \\
{[0.885]}\end{array}$ & $\begin{array}{c}-0.010 \\
{[0.616]}\end{array}$ & $\begin{array}{c}-0.014 \\
{[0.524]}\end{array}$ & $\begin{array}{c}-0.021 \\
{[0.360]}\end{array}$ \\
\hline Enrolled 3rd Spring & $\begin{array}{c}-0.017 \\
{[0.460]}\end{array}$ & $\begin{array}{c}-0.019 \\
{[0.363]}\end{array}$ & $\begin{array}{c}-0.003 \\
{[0.877]}\end{array}$ & $\begin{array}{c}-0.017 \\
{[0.388]}\end{array}$ & $\begin{array}{c}-0.017 \\
{[0.508]}\end{array}$ & $\begin{array}{c}-0.023 \\
{[0.360]}\end{array}$ \\
\hline Enrolled 4th Fall & $\begin{array}{c}-0.020 \\
{[0.400]}\end{array}$ & $\begin{array}{c}-0.022 \\
{[0.288]}\end{array}$ & $\begin{array}{c}-0.003 \\
{[0.881]}\end{array}$ & $\begin{array}{c}-0.016 \\
{[0.444]}\end{array}$ & $\begin{array}{c}-0.022 \\
{[0.392]}\end{array}$ & $\begin{array}{c}-0.026 \\
{[0.288]}\end{array}$ \\
\hline Enrolled 4th Spring & $\begin{array}{c}-0.057 \\
{[0.252]}\end{array}$ & $\begin{array}{l}-0.061 * \\
{[0.067]}\end{array}$ & $\begin{array}{c}-0.043 \\
{[0.138]}\end{array}$ & $\begin{array}{c}-0.050 \\
{[0.348]}\end{array}$ & $\begin{array}{c}-0.050 \\
{[0.248]}\end{array}$ & $\begin{array}{c}-0.065 \\
{[0.224]}\end{array}$ \\
\hline Student controls? & Linear & $\begin{array}{l}\text { Group fixed } \\
\text { effects }\end{array}$ & $\begin{array}{l}\text { Linear plus } \\
\text { HS fixed } \\
\text { effects }\end{array}$ & Linear & Linear & Linear \\
\hline Institution controls? & $\begin{array}{c}\text { ACT } \\
\text { composite }\end{array}$ & $\begin{array}{c}\text { ACT } \\
\text { composite }\end{array}$ & $\begin{array}{c}\text { ACT } \\
\text { composite }\end{array}$ & $\begin{array}{c}\text { ACT } \\
\text { composite } \\
\text { plus spending } \\
\text { controls }\end{array}$ & $\begin{array}{l}\text { ACT } \\
\text { composite } \\
\text { plus } \\
\text { selectivity } \\
\text { control }\end{array}$ & $\begin{array}{c}\text { ACT } \\
\text { composite } \\
\text { plus faculty } \\
\text { resource } \\
\text { control }\end{array}$ \\
\hline
\end{tabular}

Notes: Each cell reports the coefficient on indicator for "flat pricing" from a separate regression. For the cumulative credits outcomes, the sample is restricted to students enrolled (part-time or full-time) in all fall and winter semesters since high school graduation and for which NSC and STARR data agree on enrollment history. Cumulative credits include credits taken during summer terms. For the persistence outcomes, "Flat Pricing" describes the pricing policy of the first institution attended and the sample is restricted to MI public high school graduates from 2008 to 2011 that enrolled in a MI public university in the fall immediately after high school graduation. All observations associated with the University of Michigan-Ann Arbor are excluded from the analytic samples. All models include indicators for term (if outcome is measure of cumulative credits) or high school cohort (if outcome is measures of persistence); indicators for female, black, Hispanic, other race, LEP and FARM, as well as composite ACT score. Except for columns (2) and (3), in which p-values are based on standard errors clustered by college, p-values calculated using the wild bootstrap approach (with 500 repetitions) recommended by Cameron, Gelbach, and Miller (2008) for few clusters appear in brackets: *** $\mathrm{p}<0.01, * * \mathrm{p}<0.05$, * $\mathrm{p}<0.1$. 


\section{Appendix B: Extensions to Basic Static Model}

The basic model described in the text omits four potentially important features of postsecondary schooling: investment over time, nonlinear returns, uncertainty, and investment "lumpiness.” This Appendix develops the implications of these features.

Investment over time. Extending the analysis to more than one period, by itself, has little impact on our qualitative predictions. Suppose earnings are linear in total credits accumulated over multiple periods. If pricing is also linear, then the well-known consumption smoothing result prevails; students will choose the same credit load in each period. However, the introduction of nonlinear pricing separately in each period means that three possible outcomes satisfy the first-order conditions. Some students will choose equal credit loads across all periods at $z_{\text {low }}$, below full-time status (on the lower segment of the budget constraint). Others will choose equal credit loads across all periods at $z_{\text {high }}$, above full-time status. Some may also find it optimal to choose $z_{\text {high }}$ in one period and $z_{\text {low }}$ in another if this switching equilibrium dominates either of the constant ones. That is, utility may be maximized by exerting the extra effort cost and achieving the higher marginal return for one (but not all) periods. ${ }^{1}$ As with the one-period model, switching from a linear to flat pricing schedule will have the greatest impact on credits taken (in either period) for those who would otherwise locate at the full-time minimum.

Nonlinear returns. Perhaps the most controversial simplification of the basic model described in the main text is that it assumed each course credit increases lifetime earnings by the same increment. This simplification permitted us to focus on the nonlinearities created by tuition policies. However, there is evidence that the return to college education is nonlinear due to strong "sheepskin” effects. The final credit earned to complete a degree has a much higher return

\footnotetext{
${ }^{1}$ A switching optimum with $z_{1}=z_{l o w}$ and $z_{2}=z_{\text {high }}$ will satisfy the FOC as long as $\frac{\delta u / \delta z_{1}}{\delta u / \delta z_{2}}=\frac{w-t_{1}}{w-t_{2}}$. Whether this dominates the constant-credit outcomes depends on the utility function.
} 
than the first few credits earned toward the same degree. First consider a one-period model where each increment of schooling increases earning potential by a fixed amount $w$ up to a threshold level $\bar{z}$, at which point earnings jump by a discrete amount $\theta$ and are constant thereafter. Thus $E(z)=(w z) \cdot 1(z<\bar{z})+(w \bar{z}+\theta) \cdot 1(z \geq \bar{z})$. In this case, the nonlinear return will dominate intensity decisions. Students will bunch precisely at the $\bar{z}$ since it will never be optimal to choose a level $z>\bar{z}{ }^{2}$ Thus many students (who otherwise choose enough credits to achieve the nonlinear return) will be unaffected by a shift from linear to flat pricing. However, the shift will draw more people into the return kink, inducing them to acquire the degree. Again, those on the margin of graduating should be most affected by this marginal price change. This same logic applies to the setting with multiple time periods, nonlinear returns, and no uncertainty. Since credits earned in different time periods are perfect substitutes in the earnings production function, students' choice problem is similar in all periods. Thus decisions will be similarly sensitive to marginal price in earlier or later time periods.

Uncertainty. The model assumes that people choose credit loads with perfect foresight about future preferences (e.g., effort costs), credit completion, enrollment, and degree completion. Uncertainty along these dimensions alters the choice environment as it is resolved over time. For instance, freshmen may be uncertain about future life events that may cause them to drop out, enroll part-time, or otherwise switch budget constraint segments next year. Since the payoffs to current decisions depend, in part, on these uncertain future outcomes, current choices will be less responsive to price when uncertainty is greatest, such as in the earliest years. Students in later years of college, facing less uncertainty, should respond more sharply to changes in price schedule.

\footnotetext{
${ }^{2}$ If we permit additional credits beyond $\bar{z}$ to increase earnings, some students will locate at $z>\bar{z}$, but there will still be a mass of students at $\bar{z}$.
} 
Investment lumpiness. Lastly, the above discussion treats schooling intensity as continuous, though in practice the number of credits is finite and "lumpy" as most classes are worth either 3 or 4 credits. Such adjustment costs have been found to mute responses to nonlinear incentives in other contexts (Chetty et al., 2011). 


\section{Appendix C: Additional Figures}

Figure C1. Likelihood of Attending a Flat-Pricing Institution, Exclude UM-AA

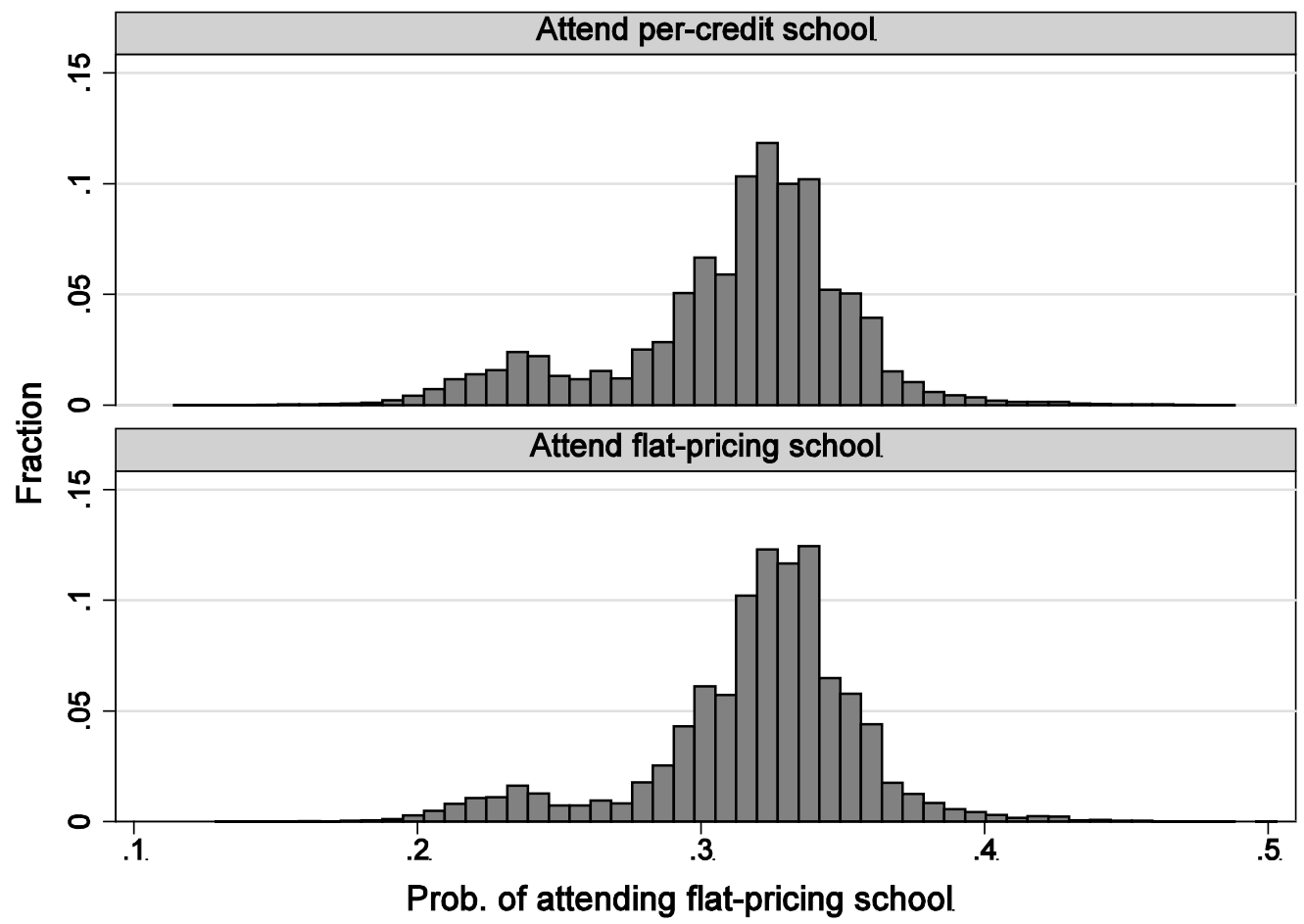

Notes: Graphs depict distributions of predicted probabilities from a probit model of attending a flat-pricing institution by school type (i.e., flat or per-credit) as a function of student-level characteristics. Sample includes all students (regardless of enrollment intensity). 
Figure C2. Likelihood of Attending a Flat-Pricing Institution, Include UM-AA

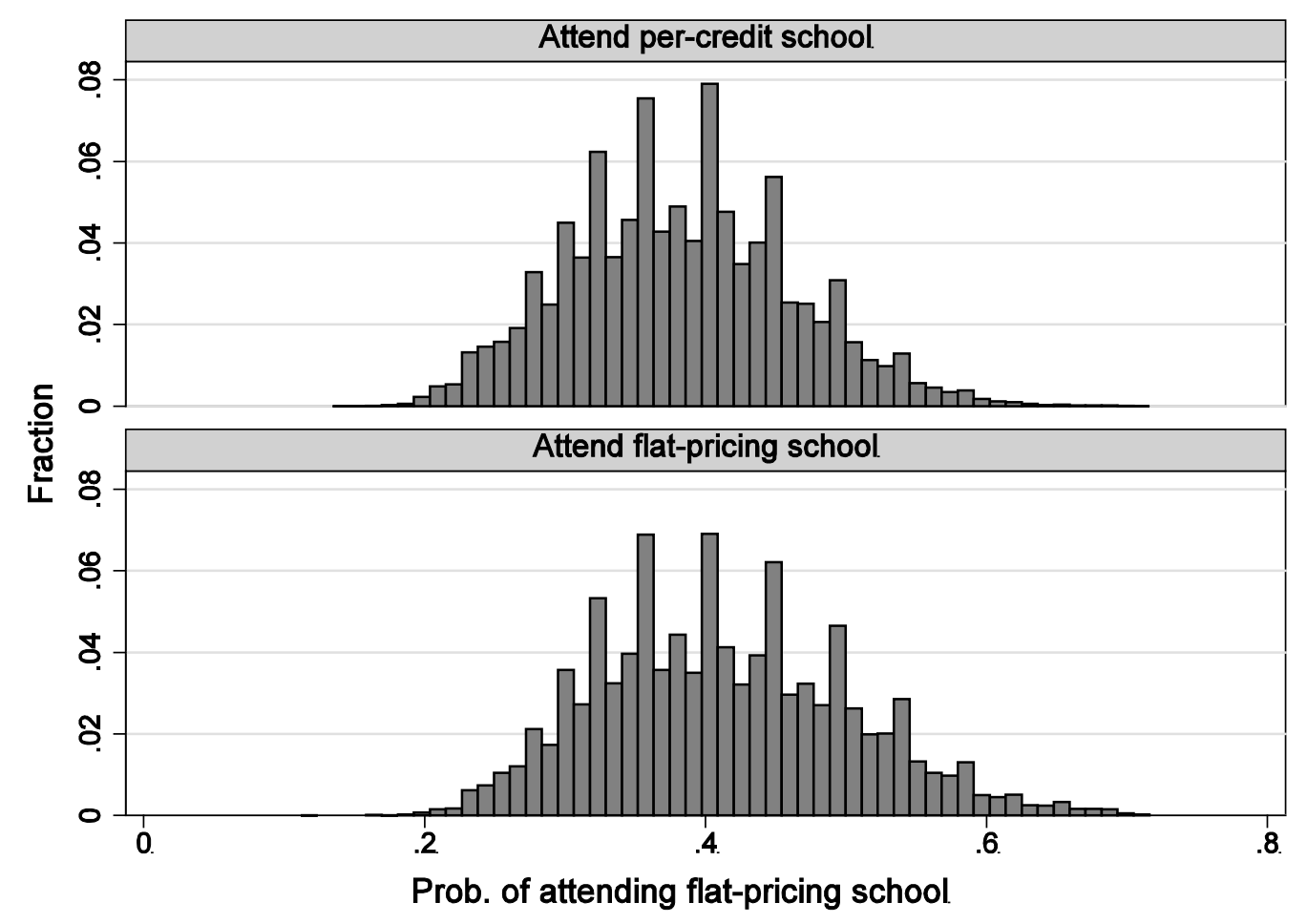

Notes: Graphs depict distributions of predicted probabilities from a probit model of attending a flat-pricing institution by school type (i.e., flat or per-credit) as a function of student-level characteristics. Sample includes all students (regardless of enrollment intensity). 


\section{Figure C3. DFL-Reweighted Estimates of Flat-Pricing Effects}

\section{A. Credits Attempted}
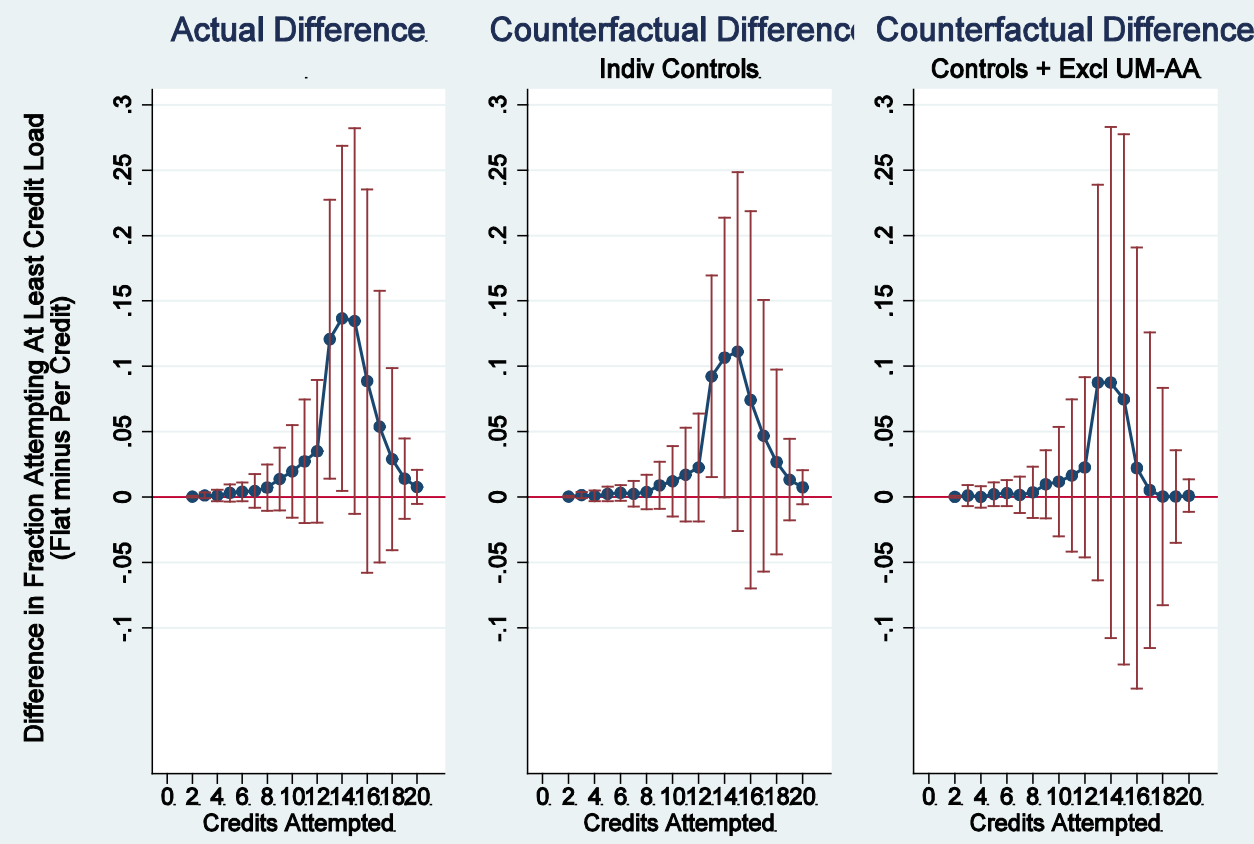

B. Credits Earned
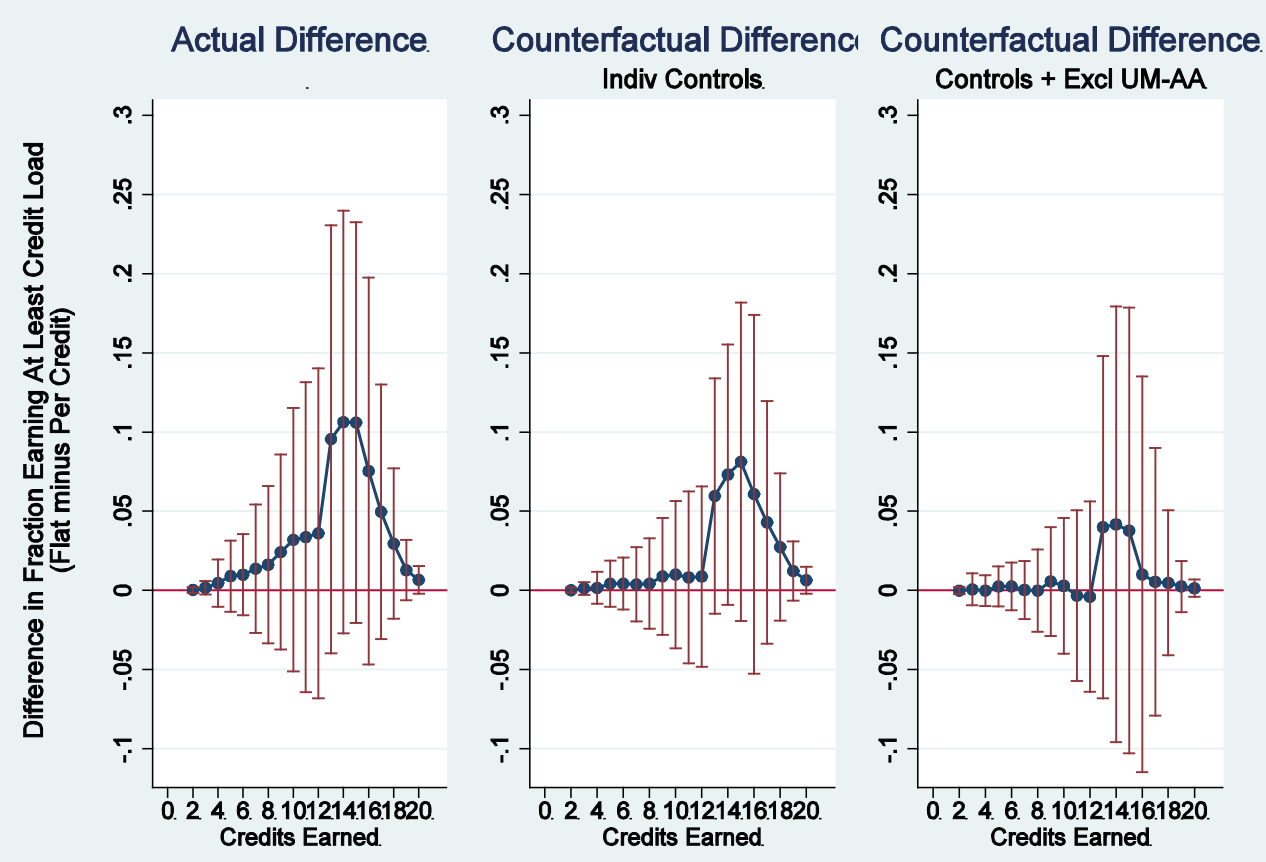

Notes: Figures plot the difference in distributions of credits attempted and earned, weighting students at per-credit schools to mirror the observable characteristics of students at flat-pricing institutions as described by DiNardo, Fortin, and Lemieux (1996). 95\% confidence intervals are constructed using 500 bootstrapped replications, resampling entire institutions to account for the within-institution correlation of outcomes. 
Figure C4. Persistence Among Fall Enrollees at MI Public Universities, by High School Cohort and Pricing Policy

\section{A. Persistence at Any College}

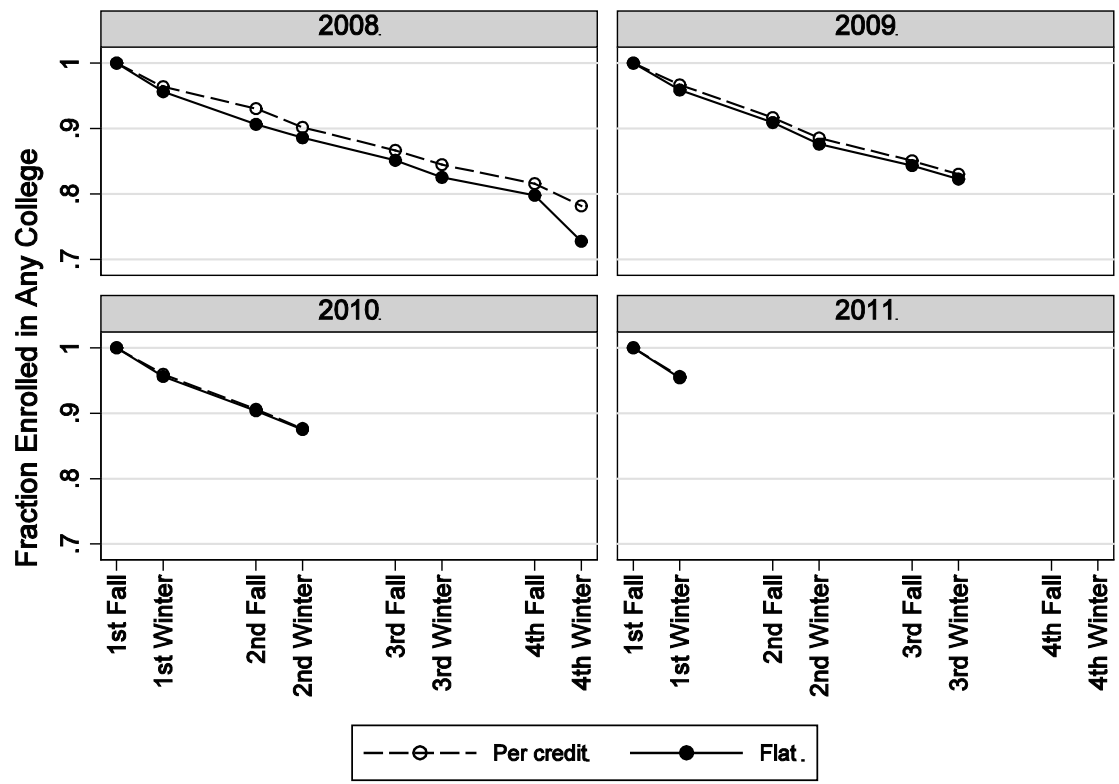

\section{B. Persistence at Any MI Public 4-year University}

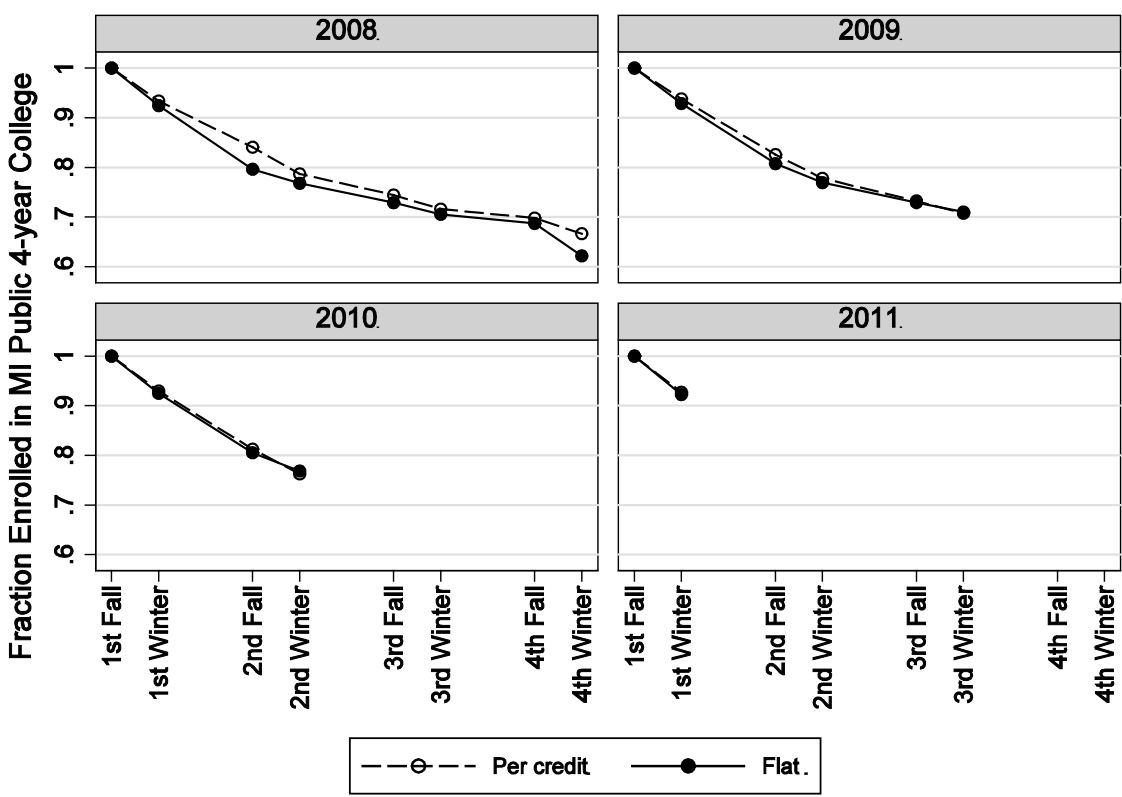

Notes: Figures plot the fraction of students enrolled in any college (Panel A) or a MI public university separately by high school cohort and pricing policy of first institution. Underlying sample is restricted to MI public high school graduates from 2008 to 2011 that enrolled in a MI public 4-year university in the fall immediately after high school, excluding University of Michigan-Ann Arbor. 


\section{Appendix D: External Validity}

Our study focuses on public universities in Michigan because of the availability of rich transcript data and because the state appears unique in having substantial policy variation among similar institutions, likely because tuition policy is not set centrally. While focusing on a single state and sector controls for many possible confounders, it raises the question of external validity. Unfortunately there is no systematic source of information of the current use of flat or per-credit pricing across many institutions nationally, so repeating our analysis for a wide range of schools is not possible. ${ }^{3}$ As a check on external validity, in Table D1 we examine students at public universities in the states of Minnesota and Texas using data contained in the 2004 and 2008 National Postsecondary Student Aid Study (NPSAS). These states have nationally representative samples for students in public universities in both these years and, importantly, have some variation in pricing practices across institutions and over time. ${ }^{4}$

Within the University of Minnesota System, the Duluth and Crookston campuses transitioned from per-credit to flat pricing between 2004 and 2008, while the Twin Cities and Morris campuses were flat throughout. Three of the Minnesota State Universities had flat pricing and four had per-credit pricing in 2004, with one (Southwest State) going from per credit to flat between 2004 and 2008. Though cross-sectional models suggest a positive association between flat pricing and credit intensity, including institution fixed effects eliminates this pattern. Though the Duluth and Crookston campuses adopted flat pricing, their students did not gain on those at

\footnotetext{
${ }^{3}$ Standard sources such as the Integrated Postsecondary Education Data System (IPEDS) by the U.S. Department of Education and the Annual Survey of Colleges by the College Board ask institutions to report the price for a typical full-time student, but do not currently report whether this price varies with credit load. This is a point also made by Baum et al (2013). IPEDS does contain an indicator for flat or per-credit pricing in 1993, but data from this period would have limited applicability to the external validity of our results in 2011.

${ }^{4}$ Other states with representative or large samples in NPSAS in 2004 and 2008 lack adequate variation in pricing practices across institutions. For instance, all public 4-year universities in California, New York, Ohio, and North Carolina have flat pricing structures, as do most in Georgia. Flat pricing in Illinois is confined to the two most selective institutions (University of Illinois Urbana-Champaign and University of Illinois Chicago) with no change, making credible comparisons difficult. All public universities in Florida charge per credit hour.
} 
the Twin Cities and Morris campuses where pricing policy was unchanged. ${ }^{5}$ In Texas, flat pricing was introduced at five campuses in the wake of tuition deregulation in 2003 (Kim and Stange, 2015): the University of North Texas (2007), UT Austin (2005), UT Arlington (2006), UT Brownsville (2006), and Texas A\&M (2009). Prior to that, all institutions charged per credit. Again we find little evidence that credit intensity increased appreciably following the adoption of flat pricing, whether we examine the entire sample or restrict analysis to the UT System.

\footnotetext{
${ }^{5}$ Some cautions are warranted. The samples are very small and not representative at a school level. Also, data cleaning measures used in 2008 eliminate $87 \%$ of the sample of students at the seven Minnesota State campuses during that year. These observations are dropped from all analysis and preferred specifications do not use Minnesota State campuses in 2008.
} 
Table D1. Effect of Flat Pricing on Credits Attempted, Other States

\begin{tabular}{|c|c|c|c|c|c|}
\hline \multirow{2}{*}{$\begin{array}{l}\text { Panel A. Minnesota } \\
\text { Sample } \\
\end{array}$} & \multirow[b]{2}{*}{ Controls } & \multirow[b]{2}{*}{ Obs. } & \multicolumn{3}{|c|}{ Credits Attempted } \\
\hline & & & At least 13 & At least 15 & Average credits \\
\hline All schools, All years & Full controls & 1500 & $\begin{array}{c}0.093 * * * \\
(0.031)\end{array}$ & $\begin{array}{c}0.120^{* * *} \\
(0.044)\end{array}$ & $\begin{array}{c}0.578 * * * \\
(0.176)\end{array}$ \\
\hline UMN System, All years & Full controls & 900 & $\begin{array}{c}0.075^{*} \\
(0.043)\end{array}$ & $\begin{array}{c}-0.023 \\
(0.065)\end{array}$ & $\begin{array}{c}0.256 \\
(0.252)\end{array}$ \\
\hline UMN System, All years & Full controls + Fixed effects & 900 & $\begin{array}{c}0.010 \\
(0.051)\end{array}$ & $\begin{array}{c}-0.117 \\
(0.089)\end{array}$ & $\begin{array}{l}-0.113 \\
(0.317)\end{array}$ \\
\hline Overall sample mean & & 1500 & 0.916 & 0.669 & 15.20 \\
\hline \multicolumn{3}{|l|}{ Panel B. Texas } & \multicolumn{3}{|c|}{ Credits Attempted } \\
\hline Sample & Controls & & At least 13 & At least 15 & Average credits \\
\hline All schools, 2008 & Full controls & 2900 & $\begin{array}{c}0.014 \\
(0.030)\end{array}$ & $\begin{array}{l}-0.033 \\
(0.031)\end{array}$ & $\begin{array}{l}-0.098 \\
(0.109)\end{array}$ \\
\hline UT System, All years & Full controls & 1600 & $\begin{array}{c}0.019 \\
(0.044)\end{array}$ & $\begin{array}{c}-0.095 * * \\
(0.043)\end{array}$ & $\begin{array}{l}-0.167 \\
(0.152)\end{array}$ \\
\hline UT System, All years & Full controls + Fixed effects & 1600 & $\begin{array}{l}-0.056 \\
(0.060)\end{array}$ & $\begin{array}{c}0.009 \\
(0.061)\end{array}$ & $\begin{array}{l}-0.048 \\
(0.211)\end{array}$ \\
\hline Overall sample mean & & 4800 & 0.677 & 0.407 & 13.90 \\
\hline
\end{tabular}

Notes: Sample is drawn from the 2004 and 2008 NPSAS, which is representative of students at public 4-year institutions in these years. Sample sizes rounded to nearest 100. Each observation is a person-term, weighted by sample weights. Full controls include indicators for year and semester, age, indicator for Pell recipient, GPA, EFC, family income, undergraduate level, and system (UMN or UT). Standard errors clustered by person appear in parentheses: ${ }^{* * *} \mathrm{p}<0.01,{ }^{* *} \mathrm{p}<0.05,{ }^{*} \mathrm{p}<0.1$. 